NBER WORKING PAPER SERIES

\title{
VINTAGE CAPITAL AND CREDITOR PROTECTION
}

\author{
Efraim Benmelech \\ Nittai K. Bergman \\ Working Paper 15735 \\ http://www.nber.org/papers/w15735
NATIONAL BUREAU OF ECONOMIC RESEARCH
1050 Massachusetts Avenue
Cambridge, MA 02138
February 2010

We thank Marios Angeletos, Douglas Baird, Lucian Bebchuk, Guido Imbens, Boyan Jovanovic, Florencio Lopez-de- Silanes, Giacomo Ponzetto, Adriano Rampini, Andrei Shleifer, Jeremy Stein, and seminar participants at Berkeley, Columbia Law School, Duke, the European Summer Symposium in Financial Markets, Federal Reserve Bank of Boston, Harvard Economics, Harvard Law School, London Business School, London School of Economics, Northwestern, Ohio State University, Stanford, Stockholm School of Economics, Tilburg University, 2008 WFA meetings in Waikoloa, University of Alberta, University of Amsterdam, and the University of Illinois at Urbana-Champaign, and Yale Law School. We also thank Robert Grundy and Phil Shewring from Airclaims Inc. Alex Radu and Kate Waldock provided excellent research assistance. All errors are our own. The views expressed herein are those of the authors and do not necessarily reflect the views of the National Bureau of Economic Research.

NBER working papers are circulated for discussion and comment purposes. They have not been peerreviewed or been subject to the review by the NBER Board of Directors that accompanies official NBER publications.

(C) 2010 by Efraim Benmelech and Nittai K. Bergman. All rights reserved. Short sections of text, not to exceed two paragraphs, may be quoted without explicit permission provided that full credit, including (C) notice, is given to the source. 
Vintage Capital and Creditor Protection

Efraim Benmelech and Nittai K. Bergman

NBER Working Paper No. 15735

February 2010

JEL No. E22,E44,G32,G33,L93

\title{
ABSTRACT
}

We provide novel evidence linking the level of creditor protection provided by law to the degree of usage of technologically older, vintage capital in the airline industry. Using a panel of aircraft-level data around the world, we find that better creditor rights are associated with both aircraft of a younger vintage and newer technology as well as firms with larger aircraft fleets. We propose that by mitigating financial shortfalls, enhanced legal protection of creditors facilitates the ability of firms to make large capital investments, adapt advanced technologies and foster productivity.

\author{
Efraim Benmelech \\ Harvard University \\ Department of Economics \\ Littauer 233 \\ Cambridge, MA 02138 \\ and NBER \\ effi_benmelech@harvard.edu \\ Nittai K. Bergman \\ MIT Sloan School of Management \\ E52-437 \\ 50 Memorial Drive \\ Cambridge, MA 02142 \\ and NBER \\ nbergman@mit.edu
}




\section{Introduction}

There is a large body of evidence that better legal rules covering protection of corporate shareholders and creditors are associated with more developed financial markets and higher economic growth (La Porta et al., (1997), (1998); King and Levine, (1993); Beck et. al., (2000); and Rajan and Zingales, (1998)). While the empirical regularities found in the data are quite robust, most of the research is based on cross-country outcomes and suffers from small samples and potential identification problems (see Djankov at al. (2007)). In addition, the results from cross-country regressions do not pin down the underlying mechanism through which creditor rights and shareholder protection affect real economic outcomes. This paper attempts to fill this gap. We study the relation between creditor protection and the use of vintage capital in the airline industry in a sample of most of the aircraft in the world (489,916 aircraft-year observations) covering 5,987 operators in 129 countries in the years 1978-2003. We find that airlines enjoying the benefits of higher creditor protection operate aircraft of a newer technology and younger vintage.

The importance of new capital goods for economic growth has been suggested by Solow (1960): “...many if not most innovations need to be embodied in new kinds of durable equipment before they can be made effective. Improvements in technology affect output only to the extent that they are carried into practice either by net capital formation or by the replacement of old-fashioned equipment by the latest models..." More recent theoretical models show that capital of older vintage hampers productivity and growth (Benhabib and Rustichini (1991), Hsieh (2001)), slows technology diffusion (Chari and Hopenhayn (1991)), and increases income inequality across individuals and countries (Jovanovic (1998)). Empirical estimates suggest that around $60 \%$ of US per-capita growth is due to technical change that is embodied in new more efficient capital goods (Greenwood, Hercowitz, and Krusell (1997)). ${ }^{1}$ Our paper provides novel evidence on a financial channel in technological adaption and capital formation.

While we propose and provide evidence on one mechanism connecting financial constraints and creditor protection to aircraft vintage and fleet size, our results suggest a broader link between financial development, investor protection and economic activity. Our empirical methodology differs from previous research which has focused mostly on aggregate, macroeconomic outcomes of investor protection such as financial market development and economic growth (King and Levine (1993), La

\footnotetext{
${ }^{1}$ See Boucekkine, de la Croix, and Licandro (2008) for a survey of the vintage capital literature.
} 
Porta et al. (1997, 1998), Rajan and Zingales (1998)). The wealth of the data and our focus on an important global industry allow careful consideration and identification of the specific mechanism through which investor protection affects and fosters technical progress and economic development. ${ }^{2}$

We start by developing a simple price-theory model of an airline choosing its scale and average asset age given an internal financing constraint and an external creditor protection environment that is determined at the country level. The airline must decide on the quantity of aircraft to purchase and their average age. Older aircrafts are assumed to be less efficient - either because of depreciation in aircraft efficiency stemming from their normal use, or because of technological improvements in aircraft design over time. The model shows that increased availability of external finance due to enhanced creditor protection will have two important effects on firms. First, when creditor rights are greater, and hence financial constraints more relaxed, firms will be able to invest in newer, more expensive technologies. Second, since financing considerations will place fewer constraints on firm scale, firms will tend to be larger in countries with greater creditor rights. ${ }^{3}$

Using detailed profiles of most aircraft in the world during the period 1978-2003 we then study the relation between the level of creditor protection and two measures of aircraft vintage. The first measure of vintage is simply aircraft age, defined as the time elapsed since the date of the aircraft delivery. The second measure of vintage, called 'technological age', is calculated as the time elapsed since the model type of that aircraft was first introduced. The level of country creditor protection is measured using the creditor rights score as developed by La Porta et al. (1997, 1998), and in particular the more recent score that covers 129 countries in the years 1978-2003 (Djankov et al. (2007)). Consistent with our first prediction, our analysis shows that aircraft operated in countries with higher creditor protection are of a younger vintage and newer technology. Furthermore, we also find that operators' size are larger in countries with better creditor protection. Our regressions controls for a battery of economic development variables, legal origin, government ownership of airlines, and a country's civil aviation quality, and a variety of year, country, and airline fixed-

\footnotetext{
${ }^{2}$ Our paper adds to a growing body of literature that uses industry- and firm-level data to evaluate the effects of investor protection and financial development on resource allocation (Fisman and Love (2004), Wurgler (2000)), economic growth (Demirguc-Kunt and Maksimovic (1998), Guiso, Sapienza, and Zingales (2005)), corporate risk-taking and innovation (Acharya, Amihud, and Litov (2008), Acharya and Subramanian (2008)), and financial contracts and lending structures (Bergman and Nicolaievsky (2007), Braun (2003), Esty and Megginson (2003), Lerner and Schoar (2005), Liberty and Mian (2007), Onega and Smith (2000), and Qian and Strahan (2007)).

${ }^{3}$ Our model is closely related to Eisfeldt and Rampini (2007) who show that firms which are credit constrained purchase more used, rather than new, capital because, higher ex-post maintenance payments of used capital relaxes current ex-ante financial constraints.
} 
effects. In particular, the panel dimension of our data allows us to control for country fixed-effects and hence to identify off of changes in creditor rights within a country.

To alleviate concerns about omitted variables and to provide additional evidence in support of the financing channel of technology adoption, we conduct a number of tests which split our sample into aircraft that should be treated by the creditor rights index and those that should not be treated by this index. We begin by splitting our sample into aircraft operated by commercial and private airlines, and those operated by the military. We expect the negative relation between creditor protection and both aircraft age and fleet size to hold only for non-military operators, since private and commercial operators are those required to raise funds from outside investors in cases of cash flow shortages. Moreover, only commercial and private operators would fall under the bankruptcy provisions of the local corporate and bankruptcy laws which are the essence of the creditor rights score. In contrast, sovereign debtors are incentivized to repay creditors mainly for reputational concerns and continued access to capital markets (Bulow and Rogoff (1989a,b)). Our results confirm this first conjecture: we find that the creditor rights score is correlated with the age and fleet size of commercial and private operators but is uncorrelated with the age and size of military fleets.

Focusing on commercial and private operators, we then split our sample into planes that are leased and those which are not leased. Following Eisfeldt and Rampini (2009), we conjecture that leasing allows firms to alleviate some of the financial frictions associated with debt financing, as asset repossession is easier for a lessor than for a creditor. This difference in financing frictions implies, first, that airlines in countries with poor creditor rights will be more likely to lease rather than own aircraft, and second, that the negative relation between creditor rights and aircraft vintage described above should be concentrated amongst non-leased aircraft. We find support for both of these hypotheses in the data: i) aircraft are more likely to be leased in countries with worse creditor protection, and ii) while there is a strong statistically significant negative relation between creditor rights and non-leased aircraft, we find no relation between creditor rights and aircraft vintage amongst leased aircraft. By examining the relation between creditor right and both leased and non-leased aircraft separately, we alleviate the concern that our results are driven by variation in unobserved variables, and in particular variation in investment opportunities, correlated with variation in creditor rights. Indeed, there is little reason to suspect that increased investment opportunities should differentially impact the vintage of leased vs. non-leased aircraft. In contrast, 
the financing channel provides a clear prediction regarding the differential impact of creditor rights on the two methods of aircraft financing.

We continue by splitting the sample of commercial aircraft based on airlines' financial condition. The financing channel predicts that the negative relation between aircraft vintage and creditor rights should be stronger for airlines in poor financial health. We find that vintage of aircraft of airlines with lower leverage ratios and airlines with less debt overhang is less sensitive to creditor rights. While both leverage and long-term debt are clearly endogenous, our identification strategy relies on the interaction effects between country and firm characteristics. Furthermore, testing this prediction also alleviates the concern that a correlation between creditor rights and unobserved investment opportunities is driving our results, since there is little reason to suspect that increases in creditor rights are more strongly correlated with improved investment opportunities in financially constrained firms as compared to financially unconstrained firms.

The rest of the paper is organized as follows. Section I presents a simple price-theory model. Section II provides a description of our data sources and summary statistics. Section III presents the empirical link between aircraft age and utilization and efficiency. Section IV describes the empirical analysis of the relation between creditor rights and aircraft age and fleet size. Section V concludes.

\section{The Model}

We begin by providing a simple model of a firm facing an external financing constraint which needs to choose the vintage of the technology it will operate and its scale of operation. For simplicity, firms in our model will choose between two technologies - new and old. Our main goal is to describe the cross sectional variation in the allocation of vintage capital across firms operating in countries with creditor protection, and hence financial constraints, of varying degree. The model is related to Eisfeldt and Rampini (2007), but assumes that technologies of different vintage are characterized by different production functions.

\section{A. Technology allocation with exogenous prices}

Consider a continuous set of firms deciding on their scale of operation and deciding between the use of assets which embody either an old or a new technology. For consistency with the empirical section we refer to firms as airlines and their assets as aircraft. For simplicity, we assume that 
airlines can use only one type of technology in their fleets.

A fleet of $q_{\text {new }}$ new aircraft is assumed to provide income $f\left(q_{\text {new }}\right)$, where $f$ is twice differentiable, concave, and $f(0)=0 .{ }^{4}$ Similarly, a fleet of $q_{\text {old }}$ old aircraft is assumed to provide income $g\left(q_{\text {old }}\right)$, where again, $g$ is twice differentiable, concave, and $g(0)=0$. As is common, concavity of the production function stems from decreasing returns to scale.

Airlines are assumed to be price takers. New technology aircraft are supplied perfectly elastically at a price normalized to one while the price of an old aircraft is assumed in this section to be exogenously given at $p_{\text {old }}$.

An important aspect in the model will be the tradeoff between airline size and fleet quality. Given a fixed amount of capital expenditure, an airline will need to choose between operating a relatively large number of old technology aircraft, or a smaller number of new technology aircraft. To solve this problem it turns out useful to define an equivalence function between old and new aircraft, $h$, which relates a fleet of new aircraft of size $q_{n e w}$ to the size of the old aircraft fleet with equal income. Formally, $h$ satisfies $g\left(h\left(q_{\text {new }}\right)\right)=f\left(q_{\text {new }}\right)$, so that $h\left(q_{\text {new }}\right)$ old aircraft provide equal income as $q_{\text {new }}$ new aircraft. ${ }^{5}$

Initially, we assume that airlines have no internal funds and must purchase their fleets using funds raised in an external capital market. Each airline operates in a country with a level of protection provided to investors parameterized by $\mu$, where $\mu$ measures the fraction of income that insiders within the airline can pledge to outside investors. ${ }^{6}$ Thus, given any income $R$, the airline's pledgeable income - i.e. the maximal amount that it can guarantee as repayment to its investors is $\mu * R$, with $\mu$ between zero and one. It should be emphasized that $\mu$ is a country level parameter, determined, for example, by the legal code in which firms operate. Capital markets are assumed to be perfectly competitive, and the discount factor is taken for simplicity to be 1 .

To choose the size and technology of its fleet, each airline will compare the value of a new fleet to the value of an old one. The value of a fleet comprised of new aircraft in a country with investor

\footnotetext{
${ }^{4}$ Airline output is measured in passenger miles flown, which combined with the average ticket price, generate approximately 80 percent of airline revenue (Air Transport Association, 2007).

${ }^{5}$ Since new aircraft are assumed to be more efficient than older aircraft - either because of depreciation in aircraft efficiency stemming from their normal use, or because of technological improvements in aircraft design over time we have that $h\left(q_{\text {new }}\right)>q_{\text {new }}$ for all $q_{\text {new }}$. Clearly, also, $h=g^{-1}(f)$.

${ }^{6} 1-\mu$ can be interpreted as the fraction of income insiders can costlessly expropriate from outside investors.
} 
protection $\mu$ is given by:

$$
\begin{array}{r}
V_{\text {new }}(\mu)=\operatorname{Max}\left[f\left(q_{\text {new }}\right)-q_{\text {new }}\right] \\
\text { s.t. } q_{\text {new }} \leq \mu f\left(q_{\text {new }}\right)
\end{array}
$$

Similarly, the value of a fleet comprised of old aircraft in a country with investor protection $\mu$ is given by:

$$
\begin{array}{r}
V_{\text {old }}\left(\mu, p_{\text {old }}\right)=\operatorname{Max}\left[g\left(q_{\text {old }}\right)-p_{\text {old }} q_{\text {old }}\right] \\
\text { s.t. } p_{\text {old }} q_{\text {old }} \leq \mu g\left(q_{\text {old }}\right)
\end{array}
$$

Since capital markets are perfectly competitive, outside investors break even, so that the maximand of the maximization problems have airlines obtaining the full NPV of the project subject to the financing constraint. We further assume that $V_{\text {new }}(1)>V_{\text {old }}\left(1, p_{\text {old }}\right)$ so that in an economy without financial constraints (or in one in which firms can pledge all of their output to investors), the new technology is superior to the old technology. ${ }^{7}$

It is easy to see that the solution to (1), the new technology maximization problem, is given in the following manner (the old technology solution is analogous). Define $q_{\text {new }}^{u c}$ to be the solution to the unconstrained problem, i.e. $\operatorname{Max}_{(q)}(f(q)-q)$. If $q_{n e w}^{u c}$ satisfies the financing constraint $q^{u c} \leq \mu f\left(q^{u c}\right)$, and is hence achievable by the airline, it will be the constrained solution as well. On the other hand, if $q^{u c}$ is not achievable $\left(q^{u c}>\mu f\left(q^{u c}\right)\right)$, the financing constraint will be binding and the constrained solution will be defined implicitly by $q=\mu f(q)$. In this region, investment and firm value will be increasing in $\mu$, as increases in $\mu$ relax the financing constraint.

In choosing between the new and old technologies, an airline in a country with investor protection $\mu$ simply compares $V_{\text {new }}(\mu)$ to $V_{\text {old }}(\mu, p)$. Proposition 1 describes this choice (all proofs are provided in Appendix A):

Proposition 1. If $h$, the equivalency function between new and old technology, is convex in $q_{n e w}$, then for every $p_{\text {old }}$ there exists a $\bar{\mu} \geq 0$ such that airlines operating in countries with investor protection $\mu<\bar{\mu}$ choose the old technology, and airlines operating in countries with investor protection $\mu>\bar{\mu}$ choose the new technology.

Proposition 1 states that if $h$ is convex, the allocation of vintage capital is such that airlines

\footnotetext{
${ }^{7}$ This assumption is for expositional use only, and is no longer required once $p_{\text {old }}$ is endogenized.
} 
operating in low investor protection countries will choose an old aircraft fleet, while those operating in high investor protection countries will choose a new aircraft fleet.

One potential reason for the equivalence function to be convex is when there are economies of scale in the use of the new technology but not in the use of the old technology. For example, in the context of aircraft, there might be economies of scale in the homogenous maintenance of new aircraft, but not of older heterogenous aircraft. ${ }^{8}$ The intuition for this convexity is that because of the economies of scale, the relative advantage of the new aircraft fleet increases with its size. As the size of the new aircraft fleet increases, the marginal increase in old aircraft required to replicate the new fleet will be ever increasing - i.e. $h$ is convex. We provide a proof showing this result in Appendix A. ${ }^{9}$

To understand Proposition 1, it is useful to combine maximization problems (1) and (2) into one, by realizing that, in effect, each airline can produce income $f\left(q_{\text {new }}\right)$ in two ways - either by employing $q_{\text {new }}$ new aircraft or by employing $h\left(q_{\text {new }}\right)$ old aircraft. Thus, an airline can obtain income $f\left(q_{\text {new }}\right)$ at an effective cost of $c\left(q_{\text {new }}\right)=\min \left[q_{\text {new }}, p_{\text {old }} * h\left(q_{\text {new }}\right)\right]$. The maximization problem of an airline in a country with investor protection $\mu$ can be written therefore as

$$
\begin{aligned}
& \operatorname{Max}\left[f\left(q_{\text {new }}\right)-c\left(q_{\text {new }}\right)\right] \\
& \text { s.t. } c\left(q_{\text {new }}\right) \leq \mu f\left(q_{\text {new }}\right)
\end{aligned}
$$

Figure 1 depicts maximization problem 3 graphically in the case where $h$ is convex in $q_{n e w}$. As can be seen, the convexity of $h$ is equivalent to stating that the old technology has a comparative advantage when a firm operates on a small scale, while the new technology has a comparative advantage when the firm operates on a large scale. Indeed, if an airline operates in the region where income $f\left(q_{\text {new }}\right)$ is comparatively low, then $p_{\text {old }} * h\left(q_{\text {new }}\right)<q_{\text {new }}-$ i.e. the old technology is the efficient method of production. In contrast, if an airline operates in the region where income $f\left(q_{\text {new }}\right)$ is comparatively high then $p_{\text {old }} * h\left(q_{\text {new }}\right)>q_{\text {new }}$ and the new technology represents the efficient method of production. Economically, convexity of $h$ arises if employing new technology aircraft economizes on firm scale and organizational costs are convex in scale.

To understand Proposition 1 note that when an airline operates in a low investor protection

\footnotetext{
${ }^{8}$ We thank an anonymous referee for making this point.

${ }^{9}$ In proving this result we also show that while economies of scale lead to convexity of the equivalence function, they are not required. Indeed, assuming simply that both new and old aircraft have fixed marginal costs, and that their sole difference is that the marginal cost of new aircraft is lower than that of old ones - due, for example, to higher fuel efficiency - the equivalence function will be convex when marginal revenue is weakly concave.
} 
country (i.e. low $\mu$ ) its financial constraint will be binding and thus its operating scale and income will be limited. It will therefore choose to operate the old technology because in low scale production this is the efficient method of production. As the degree of investor protection improves the financial constraint relaxes, and firm operating scale increases. Firms therefore switch to the new technology since it is the more efficient method of production at higher levels of production.

Figure 2 presents the value functions of the two technologies as a function of $\mu$. As Proposition 1 states, low $\mu$ firms select the old technology, while high $\mu$ firms select the new technology. ${ }^{10}$

\section{B. Endogenous prices and fleet size}

We now endogenize the price of old technology, $p_{\text {old }}$. To do so, we assume that there is a finite measure of preexisting old aircraft and that $\mu$ is distributed according to some distribution function $G$. An equilibrium $p_{\text {old }}^{*}$ is a price for old technology aircraft such that the market for old aircraft clears. The equilibrium is characterized by the following proposition:

Proposition 2. If $h$, the equivalency function between new and old technology, is convex in $q_{\text {new }}$, then the equilibrium $p_{\text {old }}^{*}$ is such that there exists a $\bar{\mu}>0$ such that airlines operating in countries with investor protection $\mu<\bar{\mu}$ choose the old technology, and airlines operating in countries with investor protection $\mu>\bar{\mu}$ choose the new technology.

The intuition behind Proposition 2 is straightforward. All else equal, as the price of old technology, $p_{\text {old }}$, decreases, $V_{\text {old }}\left(\mu, p_{\text {old }}\right)$ increases compared to $V_{\text {new }}(\mu)$. Old technology therefore becomes more attractive and a larger fraction of airlines select it. The price of old technology simply decreases to the point where the demand for old technology equals the supply. Further, from Proposition 1 , we know that at the equilibrium price $p_{\text {old }}^{*}$ it is the low $\mu$ firms which are the ones who choose the old technology while the high $\mu$ firms choose the new technology. We next characterize the size of airlines' fleets as measured by their number of aircraft.

Proposition 3. There exist $\mu^{*}$ and $\mu^{* *}$ such that fleet sizes of airlines with $\mu \leq \mu^{*}$ are smaller than the fleet sizes of airlines with $\mu \geq \mu^{* *}$

Proposition 3 states that airlines operating in low $\mu$ countries are financially constrained, so that their fleet sizes are restricted. In contrast, those operating in relatively high $\mu$ countries will not be constrained, and indeed their fleet sizes will be equal to the unconstrained level.

\footnotetext{
${ }^{10}$ Both value functions become flat when the financing constraint becomes non-binding
} 
As a final step, we relax the assumption that airlines have no internal funds and must fund all of their fleet acquisition employing external finance. We prove the following proposition:

Proposition 4. If $h$, the equivalency function between new and old technology, is convex, for any level of investor protection $\mu$, there exists an $A(\mu)$, such that an airline operating in a country with investor protection $\mu$ with internal capital $A \geq A(\mu)$ employs the new-technology fleet while an airline with internal capital $A<A(\mu)$ employs the old-technology fleet. Further, $A(\mu)$ is decreasing in $\mu$.

Proposition 4 states that all else equal, firms with internal wealth above a certain threshold will employ a new technology fleet. Further, the level of internal funds at which airlines switch to the new technology is lower in countries with better investor protection. This is because these firms can more easily rely on external finance to ease their credit constraints. Internal wealth and investor protection are therefore natural substitutes in investment decisions.

From Propositions 2 through 4, we have the following three predictions which are tested in the empirical section:

Prediction 1: All else equal, airlines operating in countries with lower investor protection will have older vintage fleets.

Prediction 2: All else equal, airlines operating in low investor protection countries will have smaller fleets than those operating in high investor protection countries.

Prediction 3: The effect of the level of investor protection on airline fleet vintage will be smaller for airlines with greater internal funds.

\section{Data and Summary Statistics}

This section describes the data sources used in the empirical analysis and presents summary statistics for both aircraft age and fleet size.

\section{A. Aircraft Level Data}

Throughout our analysis we utilize data from the Ascend CASE database - a leading provider of individual aircraft and airline data which contains ownership and operating information about most commercial and corporate aircraft worldwide as well as many military and government aircraft. We construct a sample of all aircraft that are available in the database for the 129 countries that are 
included in Djankov at al. (2007). Our sample consists of all aircraft worldwide over the period January 1, 1978 to December 31, 2003 in the Ascend CASE database. ${ }^{11}$ The data are very detailed and include information on individual aircraft characteristics such as model-type, serial number, year of construction, operating airline, and owner. The data in Ascend CASE thus enables us to uniquely identify most of the aircraft in the world during the time period studied in the paper.

For each aircraft in the sample we construct two measures of aircraft vintage, which are then related to the creditor rights scores described below. The first measure is aircraft age, defined in each year as the time elapsed from the year of the aircraft's initial delivery. The second measure of vintage, which we name 'technological age', is defined as the time elapsed from the year in which the aircraft's model type was first introduced. This second measure proxies for the age of the technology that is embodied in the aircraft. The Ascend CASE database defines two aircraft-type classification - narrow and broad. We thus define two variants of technological age corresponding to the two aircraft type classification. To fix ideas consider the following example: aircraft N368AA, built in 1991, and delivered on December, 5, 1991 to American Airlines is a Boeing 767-300ER. In this case, the broad classification is the B767 model type which was first introduced in 1981. This particular variant of B767 (i.e. 300ER) was first introduced in 1986. Thus, as of the year 2008, the aircraft's age is 17 years, its technological age using the broad classification is 27 years, and its technological age using the narrow definition is 22 years.

Panel A of Table 1 displays summary statistics of aircraft age for 4 sub-periods and for the entire sample. There are 489,916 aircraft-year observations in the entire sample, with an average (median) age of 13 (12) years, and a standard deviation of 9.2 years. The sample represents 219 aircraft types, 5,987 operators from 129 countries.

In the last two columns of Panel A we split our sample into aircraft operated by commercial and private airlines (Commercial), and those operated by the military and government agencies (Military) - a distinction that plays an important role later in the analysis. There are 373,261 commercial aircraft and 116,655 that are classified as military aircraft in the sample. The commercial sample represents 161 aircraft types, 5,437 operators from 129 countries, while the military sample represents 200 aircraft types, 893 operators from 115 countries. Further, as can be seen in Panel A of the table, military aircraft are older than commercial aircraft; the average age of a commercial aircraft is 12.0 years compared to 16.0 years for military aircraft (p-value for an equal

\footnotetext{
${ }^{11}$ Benmelech and Bergman $(2008,2009)$ provide an extensive description of the Ascend CASE database.
} 
means t-test $=0.000)$.

Panel B of Table 1 presents summary statistics for broad and narrow (in parentheses) technological age. The mean broad (narrow) technological age of the entire sample is 21.9 (18.2). As in Panel A, we split our sample into commercial and military aircraft in the last two columns of Panel B. Military aircraft embody older technology than commercial aircraft; the average broad technological age of a commercial aircraft is 20.2 years compared to 27.1 years for military aircraft (p-value for an equal means t-test $=0.000)$.

\section{B. Country Level Data}

We match the data on individual aircraft to country level macro and legal variables of the aircraft's country of operator and owner. We augment the data from Ascend CASE with country level macro data from the World Bank's World Development Indicators database. This macro data includes GDP and GDP per capita in U.S. Dollars, GDP growth, GDP per capital growth, as well as country area (in sq km.) and population data. We obtain data on legal origins and creditor rights from the new database assembled by Djankov et al. (2007) that covers 129 countries in the period 1978-2003. This new data is a major improvement upon the La Porta et al. (1997, 1998) data, as it covers many more countries and tracks their variation in creditor rights score over time.

For each country, the creditor rights index measures four powers of secured lenders in bankruptcy. ${ }^{12}$ First, whether there are restrictions on bankruptcy filing; second, whether there is no 'automatic stay' or 'asset freeze' that prevent secured creditors from seizing their collateral. Third, whether secured creditors are paid first, and finally, whether a trustee different from the management runs the firm during reorganization. A value of one is assigned to each of the provisions when a country's law provides these powers to secured creditors. The creditor rights index is then calculated by aggregating the scores of the four provisions, and varies between a score of 0 (poor creditor rights) and 4 (strong creditor rights). Djankov et. al. (2007) collect time series data on creditor rights for each of the 129 countries by identifying all major reforms and assessing their impact on the creditor rights score.

Panel C of Table 1 reports summary statistics of the creditor rights index, GDP per capita, and legal origin. The mean (median) creditor rights in the sample is 1.64 (1.0) and the standard deviation is 1.01. The sample includes 276,601 aircraft from countries with English legal origin,

\footnotetext{
${ }^{12}$ See Djankov et. al. (2007) for a comprehensive description of the index and its construction.
} 
107,587 from countries with French legal origin, 50,982 from Socialist legal origin, 47,070 from German legal origin, and 7,676 aircraft are from countries with a Nordic legal origin. Table B1 in Appendix B lists the top 10 countries with the most aircraft-year observations in the sample, and the bottom 10 countries with the least aircraft-year observations. With a total of 184,122 observations, the U.S. accounts for $37.58 \%$ of the sample, followed by the Russian Federation (37,907 aircraft), U.K. (19,556 aircraft), and Canada (18,406 aircraft). The countries with the least observations in the data are Bosnia and Herzegovina (44 aircraft), Albania (49 aircraft), Niger (51 aircraft), and Togo (62 aircraft).

\section{Airline Level Data}

Finally, we match aircraft information to airline financial data where available. Information on airline financial data is obtained from Compustat Global. We collect all firms in SIC codes 45004580 and manually match them to the aircraft level data from Ascend CASE. We also supplement the information with data from Compustat North America for U.S. airlines. After matching Ascend CASE to Compustat Global and Compustat North America and restricting the sample to the countries covered by Djankov et al. (2007), we are left with a subsample of 72 airlines from 29 countries, representing a panel of 94,272 aircraft-year observations.

\section{Aircraft Vintage and Usage}

We assume that assets of an older vintage are less efficient, either because they are less technologically advanced or due to physical depreciation. We therefore begin our empirical analysis with motivational evidence testing this assumption in the context of aircraft. Measuring individual aircraft efficiency requires information on inputs (number of seats, men hour, fuel costs, operating times, routes, etc.) and outputs (number of passengers, revenue, arrival times). We cannot measure aircraft efficiency directly since we do not have access to these data at the individual aircraft level. Instead, we utilize data from the Ascend Case database on aircraft usage as an approximation of aircraft efficiency. ${ }^{13}$ Spanning the period 1996-2006, the data provides hourly utilization rates for 25,009 aircraft worldwide. For each aircraft in the sample, the data tallies the number of hours

\footnotetext{
${ }^{13}$ Airline flights commonly have what is known as a "break-even load" which is the percentage of passenger seats that must be sold to justify the flight actually occuring (Morrel 2007). Among other factors, the break-even load is influenced by the cost of flying operations (fuel costs being an important component), which implies that less efficient aircraft have higher break-even loads. Aircraft of lower efficiency are therefore flown less often.
} 
flown each year, as well as the aircraft type and year of build.

We hypothesize that if aircraft efficiency is indeed decreasing with aircraft vintage, airlines will tend to decrease the operating times of their older vintage aircraft. Thus, for example, if older vintage aircraft are less fuel-efficient airlines will shift their operations to the newer vintage aircraft in their fleet to the extent possible. Moreover, older aircraft require more maintenance and engines overhauls that would ground older aircraft for longer periods of time compared to newer ones.

Table 2 reports the results from estimating the relation between annual hourly usage and both aircraft age and aircraft technological age for all aircraft with non-zero usage. ${ }^{14}$ For each aircraftyear pair, we calculate the age of an aircraft as the time that elapsed from its year of build and the aircraft's technological age as the time elapsed from the year in which the aircraft's model type was first introduced.

As can be seen from the first column of the table, the coefficient on aircraft age is negative (-57.61) and is statistically significant at the 1\% level. Thus, consistent with our underlying assumption that older vintage aircraft are less efficient, we find that aircraft usage declines with age. This result is robust to the addition of both aircraft type and aircraft fixed effects (not reported). The economic magnitude of this effect is significant: a one-standard-deviation increase in aircraft age of 8.62 years decreases aircraft yearly usage by approximately 450 hours, representing an 18 percent decline relative to the sample mean hourly usage of 2,466 hours. In column 2 we add the log of jet fuel price (averaged through the year) as a regressor, and in column 3 we also add the interaction term between jet fuel price and aircraft age. ${ }^{15}$ As column 3 demonstrates, the interaction term is negative and significant, implying that old aircraft are utilized less when jet fuel price is high. This is very much consistent with the notion that older aircraft are less fuel efficient. A one-standard deviation increase in jet fuel price reduces the utilization of a 20-year old aircraft by 124.9 hours per year compared to a 5-year old aircraft.

Similarly, as column 4 shows, aircraft technological age is negatively related to annual hourly usage, with a one standard deviation increase in technological age reducing annual usage by 312 hours. ${ }^{16}$ Finally, as the last column of Table 2 shows, the use of old technology aircraft is more

\footnotetext{
${ }^{14}$ Since aircraft may drop out of the sample when they are retired from active service, we analyze the relation between usage and age only for aircraft that have been utilized during the year. Thus, we analyze the intensive, rather than extensive, margin, and as such our results can be viewed as a lower bound on the relation between age and utilization.

${ }^{15}$ We use the New York Harbor Kerosene-Type Jet Fuel Spot Price FOB (Cents per Gallon).

${ }^{16}$ When using technological age as a dependent variable, we do not employ aircraft-type fixed effects since this
} 
sensitive to jet fuel price than the use of new technology aircraft, consistent again with the notion that old technology aircraft are less fuel efficient.

Figure 3 provides a graphical representation of this monotonic relation between age and usage. To construct the figures we regress yearly aircraft usage on the set of indicator variables defined for each possible value of aircraft age, while including year and aircraft-type fixed effects as well. The figure graphs the coefficients on the age indicator-variables along with their 95 percent confidence interval calculated by clustering at the aircraft-type level. ${ }^{17}$ The graph illustrates the evolution of aircraft usage with aircraft age. Consistent with our assumption that aircraft efficiency improves over time, aircraft usage declines with aircraft age. We also used aircraft age as an explanatory variable instead of the set of indicator variables that were used to construct Figure 3. In unreported results we find that the coefficient on aircraft age is consistently negative and is statistically significant at the $1 \%$ level whether we cluster the standard errors by aircraft-type or at the individual aircraft level. Thus, consistent with our underlying assumption that older vintage aircraft are less efficient, we find that aircraft usage declines with age.

\section{Creditors Rights and Aircraft Vintage}

\section{A. Baseline Results}

Our simple model shows that the effects of financial constraints should be exacerbated in countries with poor creditor rights, where the availability of debt capital may be limited and its cost much higher. We therefore predict that airlines that operate in countries with poorer investor protection operate older vintage aircraft with older technologies.

To test this prediction, we calculate the age and the technological age (using both the narrow and broad measures described above) of every aircraft in the 129 countries that are in our sample during the period 1978-2003. We then run the following specification:

$$
\text { Vintage }_{\text {iact }}=\alpha \times \text { Creditor rights }_{c t}+\mathbf{X}_{c t} \lambda+\mathbf{y}_{t} \theta+\mathbf{z}_{a c} \psi+\epsilon_{\text {iact }},
$$

where the dependent variable, Vintage iact $_{\text {, }}$, is either the age or the technological age of aircraft $i$

regression would not be well identified - for any given year, all aircraft of the same type have equal technological age. Adding aircraft-type fixed effects is thus equivalent to identifying off of a simple linear time trend. Further, we do not report technological age results with aircraft fixed effects, as clearly, the coefficient on technological age in this specification is identical to that on age in the specification with aircraft fixed effects (Columns 3 and 4).

${ }^{17}$ The indicator variable for age equaling one is omitted, so that all coefficients are calculated in relation to the usage of aircraft of age one. 
operated by operator $a$ in country $c$ in year $t$. Creditor rights is the creditor rights score of country $c$ in year $t$, as measured by Djankov, et al. (2007). $\mathbf{X}_{c}$ is a vector of country-specific control variables which includes the logarithm of country c's GDP, GDP per capita, and annual rates of growth of both GDP and GDP per capita, the logarithm of its population and the logarithm of its area. In addition, in all specifications that do not include country fixed effects we include as control variables a set of indicator variables indicating the legal origin of the country - common law, French, German, Nordic, or Socialist. ${ }^{18}$ Finally, all regressions include year fixed effects, $\mathbf{y}_{t}$, and depending on the specification may also include country and operator fixed effects represented by the vector of variables $\mathbf{z}$. Since aircraft operators maintain their affiliation with the country of operation throughout the sample, country and operator fixed effects are always applied separately in each specification. All regressions are estimated with heteroscedasticity robust standard errors which are clustered by country. In our data, standard errors that are clustered by country are tenfold larger than simple robust standard errors. Thus, when we do not cluster we get a t-statistic on creditor rights that is between 19.0 and 26.8. Since our variable of interest is creditor rights which is determined at the country level, we use the higher hurdle of clustering by country. The magnitudes of the differences between the standard errors when we cluster compared to simple robust standard errors are consistent with Kloek (1981) who shows that clustered standard errors are proportional to the squared root of the number of clusters which is $\sqrt{129}=11.4$ in our sample.

Table 3 provides results of regression (4) over the entire sample. As hypothesized, we find that enhanced creditor rights are consistently negatively associated with both aircraft age as well as aircraft technological age. As the first column of Table 3 demonstrates, with year fixed effects, increasing a country's creditor rights score from 0 to 4 , reduces the age of aircraft by 1.78 years, or $13.7 \%$ of the mean aircraft age of 13 years. Adding either country or operator fixed effects (representing the 129 countries in the sample and 5,987 different operators) increases the magnitude of the negative impact of creditor rights on fleet aircraft age. With these fixed effects, a movement from a creditor rights score of 0 to a score of 4 reduces aircraft age by between 2.7 and 3.2 years, representing an approximately $20 \%$ reduction in the sample mean aircraft age.

Columns 4 to 6 of Table 3 show that enhanced creditor rights is also negatively related to aircraft technological age constructed using the broad aircraft classification scheme. This result holds when

\footnotetext{
${ }^{18}$ Country fixed effects naturally preclude using legal origin controls as there is no time series variation in legal origin in our sample period. For brevity of exposition, tables do not exhibit the coefficients on the legal origin dummy variables.
} 
using year, country and operator fixed effects. The impact of creditor rights is significant: moving the creditor rights score from 0 to 4 reduces average technological age of aircraft in an airline's fleet by between 1.6 and 2.8 years representing between 7.2 and 12.7 percent of the average technological age. ${ }^{19}$ Finally, as columns $7-9$ show, repeating the analysis using technological age defined at the narrow classification scheme yields similar results. In sum, consistent with our prediction, aircraft are younger and embody newer technology in countries with better creditor rights, controlling for GDP per capita, population, area, and a battery of fixed-effects at the operator, country and year level. We repeat the analysis in Table 3 by calculating average aircraft age within a country for each of the years, thereby collapsing the data to the country level, and estimating weighted least-squares regressions. These regressions which are not reported for brevity yield similar results.

The negative relation between creditor rights and both aircraft age and aircraft technological age points to a financing channel through which improved investor protection and its associated reduction in financial frictions affects firm investment policy and ultimately real outcomes. According to this, the ability to raise external finance is an important determinant of firm's capacity to invest in newer technologies which is a key driver of economic growth.

\section{B. Identification Strategy}

As is usually the case in cross-country analysis, the main empirical challenge is endogeneity and, in particular, an omitted variable bias problem. Specifically, the creditor rights score could be correlated with other unidentified variables, such as investment opportunities, which are in turn influencing asset vintage choices. The relation between creditor right and vintage could then be explained by effects other than the financing channel proposed in this paper. Most of the analysis that follows is aimed, therefore, at addressing the direction of causality in the empirical findings of Table 3 .

To overcome the omitted variables problem we first utilize the panel nature of our data and the changes in creditor rights over time. By including country and operator fixed effects, we control for unobserved and non-time varying heterogeneity of operators and countries. In these specifications we identify off of changes in creditor rights over time within a country. Indeed, we find that in specifications which include country fixed effects, the negative association between creditor rights

\footnotetext{
${ }^{19}$ As in columns 1 to 3 , the magnitude of the effect is larger when either operator or country fixed effects are included.
} 
and age is the largest, which is consistent with a large effect of changes in creditor rights within a country.

However, while country fixed-effects help to mitigate concerns about unobserved heterogeneity, including these fixed-effects raises the issue of the endogeneity of creditor protection laws themselves. For example, a country may revise its corporate and bankruptcy laws precisely when underlying economic conditions improve. In this case the correlation between creditor rights and aircraft vintage may merely reflect increased demand for better aircraft driven by improvements in economic conditions.

One solution for the endogeneity concern is to use an instrumental variable approach. However, variables that are correlated with creditor rights are also potentially correlated with aircraft age through channels other than the law, and hence will not meet the 'exclusion' restriction. Consider, for example, legal origins (as in La Porta et. al 1998) as an instrument for creditor rights. While correlated with creditor rights, legal origins are potentially correlated with aircraft vintage through other legal and economic mechanisms such as safety regulation or engineering quality. Djankov et. al (2007) raise similar concerns about the validity of legal origin as an instrument for creditor rights in general.

In the absence of an instrument, we identify the causal effect of creditor rights on aircraft age by splitting our sample into aircraft that are expected to be treated by stronger creditor rights and those that should not. Our identification strategy is threefold. First, we split the sample between commercial and military aircraft and show that, as expected, military aircraft are not treated by creditor rights. Second, we focus on commercial aircraft and split the sample between leased and owned aircraft. Since prior literature has shown that leasing allows firms to relax financial frictions (see e.g. Eisfeldt and Rampini, 2009), the financing channel predicts that the negative relation between creditor rights and vintage should be concentrated amongst non-leased aircraft. Our empirical results confirm the prediction that leased aircraft are not treated by the creditor rights index similarly to non-leased aircraft. Finally, we study the differential effect of creditor rights on commercial aircraft conditional on the financial health of the airline. The financing channel predicts, and we indeed find, that the relation between creditor rights and vintage is concentrated amongst airlines that are in poorer financial health. 


\section{Commercial vs. Military Aircrafts}

In Table 4, for every country, we divide our sample into aircraft operated by commercial airlines and private operators, and those operated by militaries, armed forces and government agencies. For example, as of December 31, 2003 there are ten U.S. federal agencies or military operators in our sample: Federal Aviation Administration, NASA, US Air Force, US Air National Guard, US Army, US Army National Guard, US Coast Guard, US Customs Service, US Marine Corps, and the US Navy. Likewise, as of December 31, 2003, there are four military operators and one government agency in the Islamic Republic of Iran: Iran National Cartographic Center, Iranian Air Force, Iranian Army, Iranian Navy, and the Iranian Revolutionary Guard.

We expect the negative relation between aircraft age and creditor protection to be concentrated in commercial and private aircraft operators, since these are the firms which would be required to raise funds from external investors in cases of financial shortfalls. In addition, commercial and private firms would fall under the bankruptcy provisions of the local corporate bankruptcy laws which are the essence of the creditor protection score. In contrast, government agencies, militaries and other armed forces obtain funding from their governments that are in turn subject to international law. However, when sovereign governments default on their debt creditors cannot effectively seize the country's assets. ${ }^{20}$ Instead, creditors litigate with their sovereign borrowers using international law. Sovereign borrowers are then induced to settle with their creditors as they want to maintain access to capital markets (Bulow and Rogoff (1989a,b)). In summary, corporate and bankruptcy law do not apply to aircraft operated by militaries, armed forces and government agencies.

To formally test the hypothesis that the negative relation between aircraft age and creditor protection will be concentrated in commercial and private aircraft operators, Table 4 reports the results of running regression 4 separately for commercial aircraft and aircraft operated by militaries and other government agencies. ${ }^{21}$ The dependent variable is aircraft age and the explanatory variables are as in Table 3 with the addition of the country's airforce size.

Consistent with the results in Table 3 , in all specifications, the age of commercial aircraft is

\footnotetext{
${ }^{20}$ Although lenders can potentially grab commercial or military and government-owned aircraft, this strategy is not very useful except as a strategy of harassment (Shleifer 2003).

${ }^{21}$ This specification is identical to running one regressions with all the explanatory variables interacted with a military dummy. We prefer to report the results separately for commercial and military aircraft as the exposition is clearer. Table 10 reports tests on the statistical significance of the difference between commercial and military aircraft.
} 
statistically negatively related to creditor rights with a similar economic impact found in Table 3, while the age of military aircraft is unrelated to the creditor rights score in a statistically significant manner. ${ }^{22}$ Table 5 repeats the analysis, separating the sample into commercial aircraft and aircraft operated by militaries and other government agencies, but this time using aircraft technological age as the dependant variable. Again, we find that while aircraft technological age, defined using either the narrow or broad classification, is negatively related to creditor rights in the subsample of commercial aircraft, there is no statistically significant relation between the technological age of military aircraft and country creditor rights scores. Interestingly, while not statistically significant, we find that in the subsample of military aircraft, the coefficients on creditor right scores are actually positive.

\section{Creditor Rights and Aircraft Leasing}

In the analysis above, we do not distinguish between airlines that lease aircraft instead of purchasing them through debt financing. ${ }^{23}$ Eisfeldt and Rampini (2009) show that, in the U.S., since the repossession of leased assets is easier than foreclosure on collateral of secured debt, lease financing allows for higher debt capacity than secured debt. Put differently, lease financing aids firms to circumvent some of the financial frictions associated with debt financing. To the extent that this result generalizes to other countries outside the U.S. (for example, because the title to the asset remains with the lessor but is not in the possession of a secured creditor) and too the extent that as creditor protection improves, the wedge between the availability of debt and lease financing decreases, we would expect two implications to arise. First, airlines operating in countries with poor creditor rights should be more likely to use lease financing rather than plain debt because of the associated reduction in financial frictions. Second, if leasing reduces financial frictions, then the results found in Tables 3 - 5 showing that creditor rights is negatively related to aircraft vintage should be stronger for non-leased aircraft.

To test the first conjecture, we run a probit regression on the sample of all commercial aircraft,

\footnotetext{
${ }^{22}$ We note that the main benefit of comparing military to commercial aircraft is not the comparison of their average aircraft vintage - this could be driven by technological differences - but rather the comparison of the sensitivity of their aircraft vintage to creditor protection. Showing that military aircraft vintage is not related to creditor protection can be thought of as a first test that the data should pass.

${ }^{23}$ Lease financing of aircraft is fairly common, particularly in the United States (See e.g. Benmelech and Bergman 2008 and Gavazza 2007).
} 
relating a country's creditor rights score to the likelihood of an individual aircraft being leased:

$$
\operatorname{Pr}(\text { leased }=1)=\Phi\left(-0.026 * \text { Creditor Rights } \text { ct }+\mathbf{X}_{c t} \lambda+\mathbf{y}_{t} \theta\right)
$$

where $\Phi(\cdot)$ is the standard normal cumulative distribution function, Creditor rights is the creditor rights score of country $c$ in year $t$ as measured by Djankov et al. (2007), $\mathbf{X}_{c}$ is the vector of control variables used in regression 4 , and $\mathbf{y}_{t}$ is a vector of year fixed effects. The point estimate of -0.026 $(\mathrm{p}$-value $=0.04)$ implies that airlines in countries with poor creditor rights are indeed more likely to lease their aircraft. This effect is economically significant: moving from a creditor rights score of 4 to a creditor rights score of 0 increases the likelihood that an aircraft will be leased by 10.4 percentage points, representing an increase of 24.2 percent relative to the unconditional mean. Thus, the data do indeed suggest that airlines operating in countries with low creditor protection are more likely to resort to lease financing. ${ }^{24}$

To test the second conjecture, that the negative relation between creditor rights and aircraft vintage should be stronger for non-leased aircraft, we repeat the analysis in regression 4 separately for leased and non-leased aircraft. ${ }^{25}$ Results are reported in Table 6.

Consistent with our conjecture, we find that the negative relation between aircraft vintage and creditor rights is indeed concentrated amongst owned, rather than leased, aircraft. For owned aircraft, a zero to 4 increase in creditor rights associated with a reduction of between 2.6 and 3.9 years in aircraft vintage. In contrast, in the leased aircraft subsample, in all of the specifications the coefficient on creditor rights is not statistically different from zero.

Another benefit to examining the effect of creditor right on leased and non-leased aircraft separately is that it alleviates the concern that our results are driven by variation in omitted variables and in particular variation in investment opportunities correlated with variation in creditor rights. While this concern is partly addressed by our battery of GDP-based controls, and operator and country fixed effects specifications, to the extent that time series variation in creditor rights is correlated with investment opportunities - for example because bankruptcy reform may be enacted simultaneously with other economic reforms (see e.g. Acharya and Subramanian, 2008) - we

\footnotetext{
${ }^{24} \mathrm{As}$ an aside, there must be some added cost associated with lease financing, since otherwise it would be the dominant form of raising external capital. One cost associated with leasing that is typically considered is the extra associated agency costs. These will be paid for up front by the lessee.

${ }^{25}$ As before, this specification is isomorphic to running one regressions with all the explanatory variables interacted with a leasing dummy. Table 9 reports test on the statistical significance of the difference between leased and non-leased aircraft.
} 
cannot completely rule out the possibility that variation in investment opportunities is driving the results. However, the fact that the negative relation between creditor rights on aircraft vintage is concentrated in non-leased aircraft alleviates this concern. There is little reason to suspect that increased investment opportunities should differentially impact the vintage of leased as compared to non-leased aircraft, while the financing channel provides a clear prediction regarding the differential impact of creditor rights on the two methods of aircraft financing.

One concern with our analysis in this section is that while the ability to foreclose and repossess assets is in general unique to lessors, there is one exception that also allows secured creditors to foreclose on assets in the event of bankruptcy. Section 1110 of the U.S. Bankruptcy Code provides relief from the automatic stay of assets in bankruptcy to creditors holding a secured interest in aircraft, strengthening the creditor rights of these creditors. ${ }^{26}$ Given that many non-leased aircraft are likely to be financed through secured financing, our measures of creditor rights - which includes automatic stay as one of its components - may be biased downwards for the case of the U.S.

However, we use in our empirical analysis the entire score of the creditor rights index, and given that the incidence of automatic stay is highly correlated with the general leniency towards borrowers, our results are unlikely to be driven by the provision of Section 1110 of the U.S. Bankruptcy Code. Nevertheless, we rerun our regressions by excluding all aircraft from the U.S. and find (in unreported results available upon request) that our results are unchanged even when the U.S. is excluded from the sample; our results are therefore not driven by Section 1110.

\section{E. Creditor Rights and Aircraft Leasing: Poor vs. Rich Countries}

Table 7 revisits the results of the previous table for richer (higher or equal to GDP per capita median) and poorer (below GDP per capita median) countries separately. This allows us to control better for economic development, by not only including all four GDP-based measures of development, but also allowing for a more flexible functional form in the relation between aircraft age and economic development. As can be seen in the table, we find that among the development variables, GDP per capita is the strongest predictor of aircraft age across most of the specifications with higher GDP per capita growth associated with younger aircraft.

More importantly, we find that the negative relation between creditor rights and aircraft age is

\footnotetext{
${ }^{26}$ The U.S. Bankruptcy Code began to treat aircraft financing favorably in 1957, but it was not until 1979 that Congress amended the Bankruptcy Code and introduced Section 1110 protection which provides creditors relief from the automatic stay.
} 
driven by rich countries (the coefficient on creditor rights is between -0.648 and -1.017), while for poor countries the coefficient is between -0.025 and 0.345 and is not statistically different from zero. There are fewer aircraft in the poor countries sample compared to the rich countries sample $(35,313$ vs. 177,937 observations). However, since we cluster the standard errors by country and given that there are roughly the same number of countries in each of the sub-samples, the results are not driven by lack of statistical power in the poor countries regressions. Column 7 of Table 7 focuses on non-leased aircraft of rich countries excluding all U.S. aircraft, which account for $37.58 \%$ of all aircraft in our sample. We exclude U.S. aircraft as a robustness check to verify that our results are not driven by specific characteristics of U.S. airlines that are potentially correlated with creditor rights. The coefficient of creditor rights is very similar to our previous estimates that include the U.S. and thus our results are not driven by specific features of the U.S. airline industry.

Taken together, our results thus suggest that creditor rights are more important in richer countries which is consistent with Djankov et al. (2007) who find that creditor rights have an impact on credit markets only in richer countries. In contrast, creditor rights in poorer countries have little impact on credit market development, possibly due to their lack of enforcement.

We now turn to test the roles that creditor rights and contract enforcement play in the alleviation of financial constraints and the resultant investment in vintage capital. We follow Djankov et al. (2003) and use the enforceability of contracts index developed by Business Environmental Risk Intelligence. The index is on the scale of 0 (low enforcement) to 10 (high enforcement) and is defined as the "The relative degree to which contractual agreements are honored and complications presented by language and mentality differences." ${ }^{27}$ The index is available as a cross section of 52 countries (37 rich and 15 poor) for which we have micro-level data on aircraft. Since the index averages enforcement during the 1990s and early 2000s we restrict the analysis in regressions using contract enforcement to data for aircraft-years from 1990 onwards. The mean enforcement index in our sample is 7.48, with rich countries having higher level of enforcement compared to poor countries (7.84 compared to 4.65 with the difference significant at the $1 \%$ level). As the last two columns of Table 7 clearly show, creditor rights has a strong and significant negative relation with aircraft age in rich countries while enforcement is not statistically significant. In contrast, in poor countries, enforcement is more important than creditor rights. An increase of one point in the enforcement index lowers aircraft age by 3.9 years in poor countries while the effect of creditor

\footnotetext{
${ }^{27}$ See Knack and Keefer (1995) for the exact definition.
} 
rights is not statistically significant. The results in the last two columns of Table 7 support the conjecture that creditor rights in poorer countries have little impact as they are unlikely to be enforced.

\section{F. Robustness Tests: Government Ownership and Regulation}

We now turn to check the robustness of our results in several ways. First since many commercial airlines are either fully or partially state-owned we need to control directly for government ownership in our regressions. One concern about government ownership is that it is correlated with creditor rights and hence potentially biasing our point estimates. Similarly, differences in aviation regulation may influence aircraft vintage while at the same time be correlated with a country's creditor rights index. Thus, we need direct measures of both government ownership at the airline level, and aviation regulation quality at the country level.

\section{F.1 Government Ownership, Creditor Rights and Aircraft Vintage}

The financing channel would predict that commercial airlines with government ownership can utilize the government as a source of capital to ease financing constraints. Commercial airlines wholly or partially owned by the government may have a 'soft' budget constraint and as a result should have fleets of younger vintage. Furthermore, governments may be willing to invest more in new aircraft in their 'flag carriers' as they represent the country internationally. According to Littlejohns and McGairl (1998): "Because a new aircraft symbolizes not only the nation's prestige, but also the skill of its leaders, it is easy for politicians to value these symbols far above mere prudence." 28 We collect data on government ownership in airlines from Ascend Case, and supplement it with information from airline web sites and Lexis-Nexis to construct a dummy variable taking on the value of 1 for airlines with some government ownership in a particular year, and zero otherwise.

We then run regressions similar to the specification in regression 4 for all commercial aircraft with the government ownership dummy as an additional control. The sample is divided into leased and non-leased aircraft, and results are presented in Table 8. First, as hypothesized, and consistent with a financing channel for vintage capital, government ownership is negatively related to aircraft vintage, suggesting that governments do indeed relieve some of the financial constraints of the airlines which they own. Moreover, even after controlling for government ownership, creditor

\footnotetext{
${ }^{28}$ Littlejohns and McGairl (1998) p. 216.
} 
rights is negatively related to both aircraft age and technological age of non-leased aircraft. The coefficients of creditor rights in the different specifications (between -0.619 and -1.067) are generally higher than those found in the panel data regressions.

\section{F.2 Aviation Regulation, Creditor Rights and Aircraft Vintage}

As an additional robustness test, in Table 9, we add to the regressions in Table 8 a measure of the quality of aviation regulation for country $c$ at year $t$. We construct this measure using information from the Federal Aviation Administration (FAA) that ranks the overall quality of a country's civil aviation authority. FAA inspectors assess civil aviation authorities around the world based on their authorities to license and oversee air carriers in accordance with International Civil Aviation Organization (ICAO) aviation safety standards. The FAA classifies countries into two: those that are compliant with ICAO standards and those that are not compliant with ICAO standards. ${ }^{29}$

We were able to obtain data on FAA classifications for 67 countries for the years 1994-2003, resulting in a total of 188,142 aircraft. We construct a dummy variable measuring aviation quality which takes on the value of 1 for countries that comply with ICAO standards in a particular year, and zero for those that fail to comply. We then run similar specifications to regression 4 adding the aviation quality dummy as an explanatory variable. ${ }^{30}$ Column 1 reports results using the sample of all the commercial aircraft, in columns 2 and 3 the sample is divided into leased and non-leased aircraft, and in column 4 we use only military aircraft. The first four columns of Table 9 confirm our previous findings. After controlling for both government ownership and aviation regulation quality, it is only the vintage of non-leased commercial aircraft which is related to the creditor rights index while the vintages of leased commercial aircraft and military aircraft are not. Furthermore, controlling for government ownership and aviation regulation increases the impact of creditor rights as compared to our previous estimates - moving from a creditor rights score of 0 to a creditor rights score of 4 reduces non-leased commercial aircraft age by 7.38 years.

In the last 2 columns of Table 9 we test the significance of the difference between the coefficient on creditor rights in: (i) the military and commercial non-leased aircraft subsamples; and (ii)

\footnotetext{
${ }^{29}$ According to the FAA a country fails to comply if one the following deficiencies are identified: (i) lack of laws or regulations necessary to support the certification and oversight of air carriers, (ii) lack of the technical expertise, resources, and organization to license or oversee air carrier operations; (iii) lack of adequately trained and qualified technical personnel; (iv) lack of enforcement or compliance with, minimum international standards; and (v) insufficient documentation and records of certification of air carrier operations.

${ }^{30}$ We do not include operator or country fixed-effects in these regressions since the aviation quality measure hardly changes over time within a country.
} 
the commercial leased and non-leased aircraft subsamples. To do so, we first add an interaction coefficient between the creditor rights score and a dummy variable capturing whether an aircraft is a military aircraft to the previous regressions (Columns 1-4). As can be seen, the interaction coefficient is positive and significant at the $10 \%$ level, indicating that the negative relation between creditor rights and the vintage of non-leased aircraft is statistically different than that between creditor rights and the vintage of military aircraft. In Column 6 we add an interaction term between creditor rights and a dummy variable taking on the value of one if an aircraft is leased. Again, the positive coefficient on the interaction term demonstrates that the difference between the coefficients on the creditor rights variable in the leased and non-leased subsamples (Columns 2 and 3 ) is statistically significant.

\section{G. Creditor Rights, Financial Constraints and Aircraft Vintage}

We now turn to analyze the effect of creditor rights on aircraft age conditional on the financial condition of the operator. According to Prediction 3 of the model, since airlines with greater internal funds are less likely to rely on external financing, they should be less affected by the legal system in which they operate or local financial development. Thus, we expect the effect of creditor rights on aircraft age to be larger for more financially constrained airlines.

Similar to the previous section, testing this prediction alleviates the concern that creditor rights are positively correlated with unobserved investment opportunities, and that it this correlation which is driving the negative relation between creditor rights and aircraft vintage. This is because there is little reason to suspect that increases in creditor rights are more strongly correlated with improved investment opportunities in financially constrained firms as compared to financially unconstrained firms.

To test this prediction, we obtain information on airline financial data from Compustat Global. We are able to match 67 airlines from 28 countries to the countries covered by Djankov et al. (2007), representing a panel of 63,036 non-military aircraft. We then employ in our regression specification interaction terms between the country's creditor rights index and airline-level measures of financial distress. Our approach is similar to Rajan and Zingales (1998) who identify the effects of financial development on growth using interaction terms between financial development (at the country level) and financial dependence (at the industry level). Our analysis focuses on two measures of financial constraints: leverage and long-term debt, both used by Eisfeldt and Rampini (2007) which 
were found empirically to be determinants of used capital investment. We obtain similar results using other measures such as profitability. We estimate the following regression for both leased and non-leased aircraft separately:

$$
\begin{aligned}
\text { Vintage }_{\text {iact }} & =\alpha \times \text { Creditor rights }_{c t}+\beta \times \text { FinConst }_{\text {act }} \\
& +\gamma \times \text { Creditor rights }_{c t} \times \text { FinConst }_{a c t}+\mathbf{X}_{c t} \lambda+\mathbf{y}_{t} \theta+\mathbf{z}_{a c} \psi+\epsilon_{\text {iact }}
\end{aligned}
$$

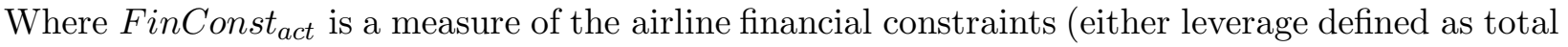
debt divided by the book value of assets, or long-term debt defined as long-term debt divided by the book value of assets), and Creditor rights $s_{c t} \times$ FinConst $_{\text {act }}$ is an interaction term between creditor rights and airline financial constraints. Regression are estimated with heteroscedasticity robust standard errors clustered by country. Results using aircraft age as the dependent variable are presented in Table 10..$^{31}$

Consistent with the financing channel, the interaction term between creditor rights and leverage and the interaction term between creditor rights and long-term debt in the non-leased aircraft subsample (Columns 1, 3, 5, 7) are negative, indicating that the effect of creditor rights on aircraft age is indeed concentrated in financially constrained airlines. In contrast, consistent with our previous results and consistent with a financing channel, we do not find a statistically significant interaction coefficient between creditor rights and measures of financial constraints in the leased aircraft subsample. While both leverage and long-term debt are clearly endogenous, our identification strategy in Table 10 relies on the interaction between country and firm characteristics. By focusing on interaction effects we reduce the number of potential alternative explanations for our findings.

Focusing on the first column of Table 10, we find that reducing a country's level of investor protection from a creditor-rights score of 4 to a creditor rights score of 0 , increases the average age of aircraft operated by airlines in the 25 th percentile of leverage by 0.95 years. In contrast, for airlines in the 75 th leverage percentile, i.e. those that are arguably more financially constrained, we find that reducing creditor rights from a score of 4 to a score of 0 increases average age by four times as much - 3.98 years, representing a 30 percent increase compared to the sample wide average of aircraft age.

\footnotetext{
${ }^{31}$ We obtain similar results using aircraft technological age as the dependent variable. We do not report these results for brevity.
} 


\section{H. Creditor Rights and Fleet Size}

We now analyze the relation between creditor rights and fleet size. According to Prediction 2 of the model, firms operating in countries with better creditor rights should operate larger fleets on average. This is because operator scale will not be constrained by the availability and cost of external finance. This prediction is broadly consistent with the empirical findings in Kumar, Rajan, and Zingales (2002) who find that the average firm size is larger in countries with better institutional development.

In order to test this prediction we need a measure of fleet size. This is somewhat complicated by the fact that airline fleets include multiple aircraft types of different size and use. Thus, a measure of fleet size must weigh aircraft of different variety in an appropriate manner. Rather than committing to one particular weight system, we test Prediction 2 using a number of weighing schemes. To do so, for each aircraft type in our sample, we gather information on that aircraft type's maximal seat capacity, its maximal takeoff weight, and the aircraft type's wingspan. This data is gathered from Singfield (2005) as well as from a variety of Internet sources. Based on this information, for each operator and year in our sample, we then construct four measures of fleet size. The first is simply an equal-weighted sum of all aircraft operated. The remaining three measures of fleet size are: (1) the sum of the seat capacities of all aircraft in the fleet, (2) the sum of the maximal takeoff weight of all aircraft in the fleet, and (3) the sum of the wingspans of all aircraft in the fleet.

Having constructed these four fleet-size measures, we then run the following regression specification for all operator fleets in our sample period of 1978-2003:

$$
\log \left(\text { Size }_{\text {act }}\right)=\alpha \times \text { Creditor rights } s_{c t}+\mathbf{X}_{c t} \lambda+\mathbf{y}_{t} \theta+\mathbf{z}_{a} \psi+\epsilon_{\text {iact }},
$$

The dependant variable, $\log \left(\operatorname{Size}_{a c t}\right)$, is the logarithm of each of our four fleet-size measures for operator $a$ in country $c$ in year $t$. As usual, Creditor rights is the creditor rights score of country $c$ in year $t$, and $\mathbf{X}_{c}$ is the standard vector of country-specific control variables. All regressions include year fixed effects, $\mathbf{y}_{t}$, and operator fixed effects represented by the vector of variables $\mathbf{z}_{a}$. The regressions are estimated with heteroscedasticity robust standard errors clustered by country. Finally, as in the case of aircraft age, regression 7 is estimated separately for commercial operators and military operators.

The results are provided in Table 11. As our results demonstrate, using all four fleet-size proxies, 
the coefficient on the creditor rights index is consistently positive and statistically significant in the commercial operators regressions after controlling for GDP per capita, population, area, as well as year and operator fixed effects. In contrast to commercial operators, and consistent with our previous results, there is no robust relation between creditor rights and fleet size of military operators. None of the creditor rights coefficients are statistically different from zero in any of the military operators regressions, and the point estimates in these regressions are always lower than their commercial regressions counterparts (they are actually negative in 3 out of 4 regressions). Thus, consistent with prediction 2 of the model, airlines in countries with higher creditor rights do indeed operate larger fleets. Given that we run a semi-log specification with respect to creditor rights, the coefficient of creditor rights is equal to the percentage change in fleet size associated with a unit change in creditor rights $\left(d \log (S i z e)_{a c t} / d C R_{c t}\right)$. This effect is economically significant. For example, moving from the lowest creditor rights score of zero, to the highest score of four, increases the number of aircraft in a commercial airline's fleet by 22 percent. Moving from the lowest to the highest score of creditor rights increases total fleet seat capacity by 72.8 percent. The effect for the remaining two fleet size measures - total fleet maximal takeoff weight and total fleet wingspan - is 73.2 and 55.2 percent, respectively.

In addition, we study the relation between fleet size and creditor rights conditional on the financial constraints that an airline is facing. In results not reported, we find no evidence that the positive relation between creditor rights and fleet size exhibited in Table 11 is concentrated amongst financially constrained airlines. This could stem from a selection bias arising from the fact that accounting data availability constrains our analysis to publicly traded airlines, which tend to be the largest airlines in each country. Alternatively, this could be driven by the positive relation which arises between leverage and fleet size when airlines use debt to purchase additional aircraft.

As a final test, we analyze the relation between fleet age and fleet size. The model predicts that constrained firms should operate both smaller and older fleets. We test therefore whether smaller fleets are indeed comprised of older vintage aircraft. We regress aircraft age on the logarithm of our four measures of fleet size - the number of aircraft operated in the fleet, the sum of the seat capacities of all aircraft in the fleet, the sum of the maximal takeoff weight of all aircraft in the fleet, and the sum of the wingspans of all aircraft in the fleet - while including our standard control variables. The results are presented in Table 13. As can be seen, in all specifications we find a statistically significant negative relation between fleet size and aircraft age; as the model predicts, 
smaller fleets tend to operate older aircraft. This result is very much consistent with Eisfeldt and Rampini (2007) who show that smaller firms are more likely to employ used, as opposed to new, capital.

\section{Conclusion}

We provide novel evidence linking creditor rights and vintage capital using a panel of aircraft-level data around the world. Consistent with theories that emphasize the protection of property rights as essential for economic development, we find that better creditor rights are associated with aircraft of a younger vintage and firms with larger aircraft fleets. Further, consistent with a financing channel, we find that the association between creditor rights and aircraft vintage is concentrated amongst non-leased commercial aircraft. Finally, we find that airlines with lower leverage ratios and airlines with less debt overhang, are less sensitive to creditor rights as they may use internal funds, rather than external capital, to finance investment.

The evidence in our paper shows that legal protection of creditor rights affects both capital vintage, technological diffusion and firm scale. Better creditor protection helps airlines to mitigate financial short-falls and enhance investment in newer, more efficient and more technologically advanced aircraft. While we study the relation between vintage aircraft and creditor rights, our results propose a broader link, not confined only to the airline industry, between investor protection, real corporate investment and economic growth; legal protection of creditors facilitates the ability of firms to make large capital investments, adapt advanced technologies and fosters productivity. 


\section{Appendix A}

Proof of Proposition 1. Define $z\left(q_{\text {new }}\right)=p_{\text {old }} * h\left(q_{\text {new }}\right)$ to be the price of obtaining income $f\left(q_{\text {new }}\right)$ using a fleet of old technology aircraft. For simplicity in what follows we drop the subscript and denote $q_{\text {new }}$ by $q$. If $z^{\prime}(0) \geq 1$, from the convexity of $z$ we have that $z(q)>q$ for all $q>0$ and the proposition trivially holds with $\bar{\mu}=0$. Similarly, if $z^{\prime}(0)<1$ and $z(q)<q$ for all $q>0$ the proposition trivially holds with $\bar{\mu}=1$. Assume then that $z^{\prime}(0)<1$ and that there exists a $q>0$ with $z(q)=q$. By the convexity of $z$, this $q$ is unique, and we denote it by $q^{*}$. Clearly $z(q)<q$ for $q<q^{*}$ and $z(q)>q$ for $q>q^{*}$.

Now, for any $\mu$ we define the 'financable set' to be all $q$ with $c(q) \leq \mu f(q)$, where $c(q)=\min (z(q), q)$. Since $f$ is concave, $z$ is convex, $f(0)=0$, and $z(0)=0$ it is easy to see that for any $\mu$ the financable set equals $[0, q]$ for some $q$. Now, define $\mu^{*}$ to satisfy $\mu f\left(q^{*}\right)=q^{*}$. By definition of $q^{*}$, the financable set at $\mu^{*}$ is $\left[0, q^{*}\right]$. Since in this region $z(q)<q$ for all $q$ which are financable, a firm operating in a country with creditor protection $\mu^{*}$ chooses the old technology fleet. Similarly, for any $\mu<\mu^{*}$, the financable set equals $\left[0, q^{\prime}\right]$ for some $q^{\prime}<q^{*}$, so that again, $z(q)<q$ for all financable $q$. Thus, again, any firm operating in a country with creditor protection $\mu<\mu^{*}$ chooses the old technology.

Define $q^{u c}$ to be the solution to the unconstrained problem $\operatorname{Max}_{q}[f(q)-c(q)]$. Since by assumption the new technology is preferred to the old when $\mu=1$, we have that $c\left(q^{u c}\right)=q^{u c}$, so that $q^{u c}>q^{*}$. Define $\mu^{* *}$ to satisfy $\mu f\left(q^{u c}\right)=q^{u c}$. Clearly, for any $\mu \geq \mu^{* *}, q^{u c}$ is financable, so that a firm operating in a country with $\mu>\mu^{* *}$ chooses the unconstrained solution and hence the new technology.

Now, for all $\mu^{*}<\mu<\mu^{* *}$ the financable set equals $[0, \bar{q}(\mu)]$ for some $q *<\bar{q}(\mu)<q^{u c}$. Define $V(\mu)$ to be the solution to the maximization problem of a firm operating in a country with creditor protection $\mu^{*}<\mu<\mu^{* *}$. That is, $V=\operatorname{Max}_{q}[f(q)-c(q)]$ s.t. $q \leq \bar{q}(\mu)$. Further, define $V_{1}$ as the solution to the maximization problem $\operatorname{Max}_{q}[f(q)-c(q)]$ s.t. $q \leq q^{*}$, and $V_{2}(\mu)$ as the solution to the maximization problem $\operatorname{Max}_{q}[f(q)-c(q)]$ s.t. $q^{*} \leq q<\bar{q}(\mu)$. Clearly, $V=\max \left[V_{1}, V_{2}(\mu)\right]$ and a firm in country $\mu$ will choose the new technology iff $V_{2}(\mu)>V_{1}$. Now, it is easy to see that $V_{2}(\mu)$ is increasing in $\mu$. Also, since the new technology is preferred to the old with no constraints, we have that $V_{2}\left(\mu^{* *}\right)>V_{1}$. Thus, since $V_{1}$ is independent of $\mu$, there exists a $\mu^{*} \leq \bar{\mu}<\mu^{* *}$ such that for all $\mu^{*} \leq \mu \leq \bar{\mu}, V_{1} \geq V_{2}(\mu)$ and for all $\bar{\mu} \leq \mu \leq \mu^{* *}, V_{2}(\mu) \geq V_{1}$. Thus, firms in countries with $\mu^{*} \leq \mu \leq \bar{\mu}$ choose the old technology, while firms in countries with $\bar{\mu}<\mu \leq \mu^{* *}$ choose the new technology. This, combined with the fact that firms in countries with $\mu \leq \mu^{*}$ choose the old technology, while firms in countries with $\mu \geq \mu^{* *}$ choose the new technology proves the proposition.

Proof of Propositions 2 and 3. Proposition 2 is a direct consequence of Proposition 1, and Proposition 3 is a direct consequence of the fact that as $\mu$ tends to zero, the fleet size that is financable under the constrained maximization problem tends to zero as well.

Proof of Proposition 4. Following the proof of Proposition 1 , define $q^{*}$ to solve $z(q)=q$ and define $V_{1}$ as the solution to the maximization problem $\operatorname{Max}_{q}[f(q)-c(q)]$ s.t. $q \leq q^{*}$. Note that to obtain $V_{1}$ a firm will choose the old technology fleet since in the region $q \leq q^{*}$ this is the efficient means of production $(c(q)<q)$. Define now $V_{2}(\bar{q})$ as the solution to the maximization problem $\operatorname{Max}_{q}[f(q)-c(q)]$ s.t. $q^{*} \leq q<\bar{q}$. Since $f$ is concave, $V_{2}$ is increasing in $\bar{q}$ up to $q^{u c}$, the solution 
to the unconstrained problem. Further, since $V_{2}\left(q^{u c}\right)>V_{1}$ - i.e. the new technology is preferred to the old technology under the unconstrained solution - by continuity of $V_{2}$ and by the fact that $V_{2}\left(q^{*}\right) \leq V_{1}$ there exists a $q^{* *} \geq q^{*}$ such that $V_{2}\left(q^{* *}\right)=V_{1}$. Since $V_{2}$ is increasing in the range $\left[q^{* *}, q u c\right)$, if $q^{* *}$ is financable, the optimal solution of the firm's maximization problem, $q^{o p t}$, will satisfy $q^{o p t} \geq q^{* *}$. Since in this region the new technology fleet is the efficient means of production (i.e. $q<c(q)$ ), the firm will then choose the new technology fleet. In contrast, if $q^{* *}$ is not financable, then $q^{\text {opt }}$ will be smaller then $q^{* *}$. By definition of $q^{* *}, V_{1}$ will then be greater than $V_{2}\left(q^{\text {opt }}\right)$. In this case, therefore, the firm will choose the old technology fleet to obtain $V_{1}$.

Consider now a firm operating in a country with creditor protection $\mu$. Suppose first that $c\left(q^{* *}\right) \leq$ $\mu f\left(q^{* *}\right)$, so that a firm with no internal wealth can finance $q^{* *}$. As described above, since $q^{* *}$ is financable, the firm will employ the new technology fleet. Further, since any firm with positive internal wealth will also be able to finance $q^{* *}$, the proposition will then trivially hold with $\bar{A}=0$. Consider now the case where $c\left(q^{* *}\right)>\mu f\left(q^{* *}\right)$, so that $q^{* *}$ is not financable for a firm with no internal wealth. Define $A(\mu)=c\left(q^{* *}\right)-\mu f\left(q^{* *}\right)$. By definition, any firm with internal wealth $A \geq A(\mu)$ will be able to finance $q^{* *}$, and so, as above, will choose to employ the new technology fleet. Finally, since $q^{* *}$ is independent of $\mu$, the threshold level $A(\mu)$ is decreasing in $\mu$.

\section{Economies of Scale and the Convexity of the Equivalency Function}

In this subsection, we provide an analysis showing how economies of scale in the operation of new technology aircraft will drive the equivalency function to be convex. While we formulate the discussion by referring to aircraft, so long as a new technology provides greater economies of scale in operating costs as compared to an old technology, our results clearly generalize to other industries.

Consider an airline deciding on its scale of operation and whether to use new or old technology aircraft. New and old aircraft differ only in their associated cost structures. Marginal revenues associated with operating either an old or new fleet are assumed to be equal, for example, because passengers do not place much emphasis on the vintage of the aircraft in which they fly. Denote therefore by $p(q)$ the marginal revenue associated with operating $q$ aircraft, whether employing a new or old aircraft fleet. As usual, marginal revenue is decreasing in the quantity of aircraft operated, $p^{\prime}<0$; For example, because when an airline operates a larger fleet, it will serve more marginal markets.

Assume that operating a fleet of new aircraft involves economies of scale, for example due to the lower maintenance costs of the associated new, more homogenous aircraft. In contrast, operating a fleet of old technology aircraft does not exhibit such economies of scale, for example, because a fleet of old aircraft is more heterogenous which does not allow operating efficiencies in maintenance. Formally, we assume that the marginal cost of the old technology aircraft is constant at $c_{H}$, while the new technology's marginal cost is $c(q)$ with $c^{\prime}<0$ and $c(0)=c_{H}$.

The profit from operating $q$ new technology aircraft is $\int_{0}^{q}(p(x)-c(x)) d x$. Equivalently, the profit from operating $h$ old technology aircraft is $\int_{0}^{h}\left(p(x)-c_{H}\right) d x$. The equivalency function $h(q)$ is then defined by 


$$
\int_{0}^{q}(p(x)-c(x)) d x=\int_{0}^{h(q)}\left(p(x)-c_{H}\right) d x
$$

To investigate the conditions under which $h$ is convex, we differentiate with respect to $q$ to obtain

$$
p(q)-c(q)=\left(p(h(q))-c_{H}\right) h^{\prime}(q)
$$

Rearranging yields $h^{\prime}(q)=\frac{p(q)-c(q)}{p(h(q))-c_{H}}$. Since a firm will never choose to operate at a scale where marginal cost is greater than marginal revenue, we have that both numerator and denominator are greater than zero, implying that $h^{\prime}>0$. Further, from (8), it is easy to see that $h(q)>q$ (i.e. a fleet of new aircraft is equivalent to a larger fleet of old aircraft), which together with $c(q) \leq c_{H}$ implies that $h^{\prime}>1$.

Differentiating (9) with respect to $q$ once more and rearranging yields:

$$
h^{\prime \prime}(q)=\frac{p^{\prime}(q)-c^{\prime}(q)-p^{\prime}(h(q))\left(h^{\prime}(q)\right)^{2}}{p(h(q))-c_{H}}
$$

Since the denominator is positive, the equivalency function $h$ is convex when:

$$
p^{\prime}(q)-c^{\prime}(q)-p^{\prime}(h(q))\left(h^{\prime}(q)\right)^{2}>0
$$

It is therefore easy to see that as the economies of scale associated with the new technology fleet increase - i.e. $c^{\prime}$ becomes more negative - the right hand side of equation (11) increases and the equivalency function $h$ is more likely to be convex. Indeed, if the economies of scale are sufficiently large, $h$ will be convex. The intuition is straightforward: because of the economies of scale, the relative advantage of the new aircraft fleet increases with its size. Therefore, as the size of a new aircraft fleet increases, the marginal increase in old aircraft required to replicate the new fleet will be ever increasing - i.e. $h$ is convex.

As an aside, from the additional terms in (11), it is readily seen that while economies of scale create convexity, they are not required. Indeed, assume that both new and old aircraft have fixed marginal costs and that the marginal cost of new aircraft, $c_{L}$ is lower than that of old ones, $c_{H}-$ for example, because of new aircraft's higher fuel efficiency.

From 11, the condition for the convexity of $h$ becomes $p^{\prime}(q)-p^{\prime}(h(q))\left(h^{\prime}(q)\right)^{2}>0$. A sufficient condition for convexity of $h$ is then than the marginal revenue $p$ is weakly concave. To see this recall that $h^{\prime}>1$, and that since $h(q)>q$, we have that $0>p^{\prime}(q) \geq p^{\prime}(h(q))$.

The intuition is as follows. Since a new aircraft fleet has lower marginal cost, the 'equivalent' old fleet will always be larger in size (i.e. $h(q)>q$ ). As the new fleet increases in size, the equivalent 
old fleet must increase as well, and further, it must do so at a faster rate than that of the new fleet (i.e. $h^{\prime}(q)>q$ ). This is due to two effects: first, new aircraft are (by assumption) advantaged in that they have lower marginal cost. Second, because the old fleet is larger than the new fleet, the marginal revenue that it obtains when it expands is smaller than that obtained by the expansion of the new fleet. To make up for these two disadvantages, when the new fleet expands, the equivalent old fleet must expand by a greater amount. Now, when the marginal revenue function is weakly concave, the severity of the second effect (i.e. of differential marginal revenues) increases with the size of the new fleet. This is because the difference between the size of the new fleet and its equivalent old fleet increases with the size of the new fleet $(h(q)-q$ increases). Since the marginal revenue is weakly concave, this implies that the difference in marginal revenue of the old and the new fleet will increase as well. Thus, since the severity of the second effect increases with fleet size, the marginal amount by which the equivalent old fleet needs to expand is increasing in new fleet size - that is, the equivalency function $h$ is convex. 


\section{Appendix B}

Table B1

Countries with Most and Least Aircraft

\begin{tabular}{|c|c|c|c|c|c|}
\hline \multicolumn{6}{|c|}{ Countries with Most Aircraft 1978-2003 } \\
\hline & Country & Commercial & Military & Total & Share \\
\hline 1. & United States & 147,880 & 36,242 & 184,122 & $37.58 \%$ \\
\hline 2. & Russian Federation & 24,129 & 13,778 & 37,907 & $7.74 \%$ \\
\hline 3. & United Kingdom & 15,396 & 4,160 & 19,556 & $3.99 \%$ \\
\hline 4. & Canada & 15,356 & 3,050 & 18,406 & $3.76 \%$ \\
\hline 5. & France & 10,441 & 3,359 & 13,800 & $2.82 \%$ \\
\hline 6. & China & 9,499 & 3,061 & 12,560 & $2.56 \%$ \\
\hline 7. & Brazil & 6,741 & 4,662 & 11,403 & $2.33 \%$ \\
\hline 8. & Japan & 9,530 & 1,561 & 11,091 & $2.26 \%$ \\
\hline 9. & Germany & 10,120 & 793 & 10,913 & $2.22 \%$ \\
\hline 10. & Spain & 6,053 & 3,119 & 9,172 & $1.87 \%$ \\
\hline \multicolumn{6}{|c|}{ Countries with Least Aircraft 1978-2003 } \\
\hline 120. & Macedonia & 90 & 0 & 90 & $0.018 \%$ \\
\hline 121. & Burundi & 87 & 0 & 87 & $0.018 \%$ \\
\hline $122-3$. & Haiti & 71 & 11 & 82 & $0.017 \%$ \\
\hline $122-3$. & Benin & 82 & 0 & 82 & $0.017 \%$ \\
\hline 124. & Rwanda & 79 & 0 & 79 & $0.016 \%$ \\
\hline 125. & Central African Republic & 67 & 0 & 67 & $0.014 \%$ \\
\hline 126. & Togo & 18 & 44 & 62 & $0.013 \%$ \\
\hline 127. & Niger & 17 & 34 & 51 & $0.010 \%$ \\
\hline 128. & Albania & 49 & 0 & 49 & $0.010 \%$ \\
\hline 129. & Bosnia and Herzegovina & 44 & 0 & 44 & $0.009 \%$ \\
\hline
\end{tabular}

This table ranks countries based on the total number of aircraft in the sample. Share is total aircraft divided by total aircraft in the sample. 


\section{References}

Acharya, Viral V., and Krishnamurthy Subramanian, "Bankruptcy Codes and Innovation," Review of Financial Studies, Forthcoming (2008).

Acharya, Viral V., Yakov Amihud, and Lubomir Litov, "Creditor Rights and Corporate Risktaking," Working Paper (2008).

Air Transport Association, "The Airline Handbook", 2007

Beck, T., R. Levine, and N. Loayza, "Finance and the Sources of Growth," Journal of Financial Economics, 2000.

Benhabib, Jess and Aldo Rustichini, "Vintage Capital, Investment, and Growth," Journal of Economic Theory, 55 (1991), 323-339.

Benmelech, Efraim, and Nittai K., Bergman, "Liquidation Values and the Credibility of Financial Contract Renegotiation: Evidence from U.S. Airlines ," Quarterly Journal of Economics,(2008), 123(4) 1635-1677..

Benmelech, Efraim, and Nittai K. Bergman "Collateral Pricing," Journal of Financial Economics, (2009), 91(3) 339-360.

Bergman, Nittai, K., and Daniel Nicolaievsky "Investor Protection and the Coasian View," Journal of Financial Economics, 2007.

Braun, Matias, "Financial Contractibility and Assets' Hardness," Mimeo, 2003.

Boucekkine, Raouf, David de la Croix, and Omar Licandro, "Vintage Capital," New Palgrave Dictionary in Economics, Second Edition, (2008) Forthcoming.

Bulow, Jeremy, and Kenneth Rogoff "A Constant Recontracting Model of Sovereign Debt," Journal of Political Economy, 1989a, 97(1) 155-178.

Bulow, Jeremy, and Kenneth Rogoff "Sovereign Debt: Is to Forgive to Forget?" American Economic Review, 1989b, 79(1) 43-50.

Chari, V. V., and H. Hopenhayn, "Vintage Human Capital, Growth and the Diffusion of New technology," Journal of Political Economy, 99 (1991), 1142-1165.

Demirguc-Kunt, Asli, and Vojislav Maksimovic, "Law, Finance, and Firm Growth," Journal of Finance, 53(6) (1998), 2107-2137.

Djankov, S., R., La Porta, F. Lopez-de-Silanes, and Andrei Shleifer, "Courts," Quarterly Journal of Economics, (2003), 453-517.

Djankov, S., C. McLiesh, and Andrei Shleifer, "Private Credit in 129 Countries," Journal of Financial Economics, (2007).

Eisfeldt, Andrea, and Adriano Rampini, "New or Used? Investment with Credit Constraints," Journal of Monetary Economics, 54 (2007) 2656-2681.

Eisfeldt, Andrea, and Adriano Rampini, "Leasing, Ability to Repossess, and Debt Capacity," Review of Financial Studies, (2009), 1621-1657.

Esty, Benjamin, and William Megginson, "Creditor Rights, Enforcement, and Debt Ownership Structure: Evidence from the Global Syndicated Market," Journal of Financial and Quantitative Analysis, 38(1) (2003), 37-59. 
Fisman, Raymond, and Inessa Love, "Financial Development and Intersectoral Allocation: A New Approach," Journal of Finance, 59(6) (2004), 2785-2807.

Gavazza, Alessandro, "Asset Liquidity and Financial Contracts: Evidence from Aircraft Leases," Working paper, Yale University (2007).

Greenwood J., Z., Hercowitz, and P. Krusell, "Long-Run Implications of Investment Specific Technological Change," American Economic Review, 87 (1997), 342-362.

Guiso, Luigi, Paola Sapienza, and Luigi Zingales, "Does Local Financial Development Matter?," Quarterly journal of Economics, 119(3) (2004), 929-969.

Hsieh, Chang-Tai, "Endogenous Growth and Obsolescence," Journal of Development Economics, 66 (2001), 153-171.

Jovanovic, Boyan, "Vintage Capital and Inequality," Review of Economic Dynamics, 1 (1998) 497530.

King, Robert, and Ross Levine, "Finance and Growth: Schumpeter Might Be Right," Quarterly Journal of Economics 108 (1993), 717-738.

Kloek, T., "OLS Estimation in a Model where a Microvariable is Explained by Aggregates and Contemporaneous Disturbances are Equicorrelated," Econometrica 49 (1981), 205-207.

Knack, Stephen, and Philip Keefer, "Institutions and Economic Performance: Cross-Country Tests Using Alternative Institutional Measures," Economics and Politics VII (1995), 207-227.

Kumar, Krishna B., Raghuram G., Rajan, and Luigi Zingales, "What Determine Firm Size?," Working Paper University of Chicago GSB, (2002).

La Porta, R., F. Lopez-de-Silanes, Andrei Shleifer, and Robert Vishny, "Legal Determinants of External Finance," Journal of Finance, (1997).

La Porta, R., F. Lopez-de-Silanes, Andrei Shleifer, and Robert Vishny, "Law and Finance," Journal of Political Economy, (1998).

La Porta, R., F. Lopez-de-Silanes, and Andrei Shleifer, "The Economic Consequences of Legal Origin," Working Paper Harvard University, (2007).

Lerner, Josh, and Antoinette Schoar, "Does Legal Enforcement Affect Financial Transactions? The Contractual Channel in Private Equity," Quarterly Journal of Economics, 120(1) (2005), 223-246.

Liberty, Jose, and Atif Mian, "Collateral Spread and Financial Development," Working paper, University of Chicago (2007).

Littlejohns, Andrew, and Stephen McGairl, eds., Aircraft Financing (third edition), (Euromoney Books, England), 1998.

Peter S. Morrel, Airline Finance (second edition), (Ashgate, USA), 2007

Ongena, Steven, and David Smith, "What Determines the Number of Bank Relationships? CrossCountry Evidence," Journal of Financial Intermediation, 9(1) (2000), 26-56.

Qian, Jun, and Philip E., Strahan. "How Law and Institutions Shape Financial Contracts: The Case of Bank Loans," Journal of Finance, (2007) Forthcoming.

Rajan, Raghuram G., and Luigi Zingales, "Financial Development and Growth," American Economic Review, 88 (1998), 559-586.

Solow, R., "Investment and Technological Progress," In K. Arrow, S. Karlin, and P. Suppes (eds.) Mathematical Methods in Social Sciences 1959, (1960), 89-104. Stanford University Press. 
Shleifer, Andrei, "Will the Sovereign Market Survive?," American Economic Review, 93(2) (2003), 85-90.

Shleifer, Andrei, and Robert W. Vishny, "Liquidation Values and Debt Capacity: A Market Equilibrium Approach," Journal of Finance, 47 (1992), 143-66.

Singfield, Tom, "Airliners Worldwide - 2nd Edition," Midland Publishing, 2005

Wurgler, Jeffrey, "Financial Markets and the Allocation of Capital," Journal of Financial Economics, 58 (2000), 187-214. 


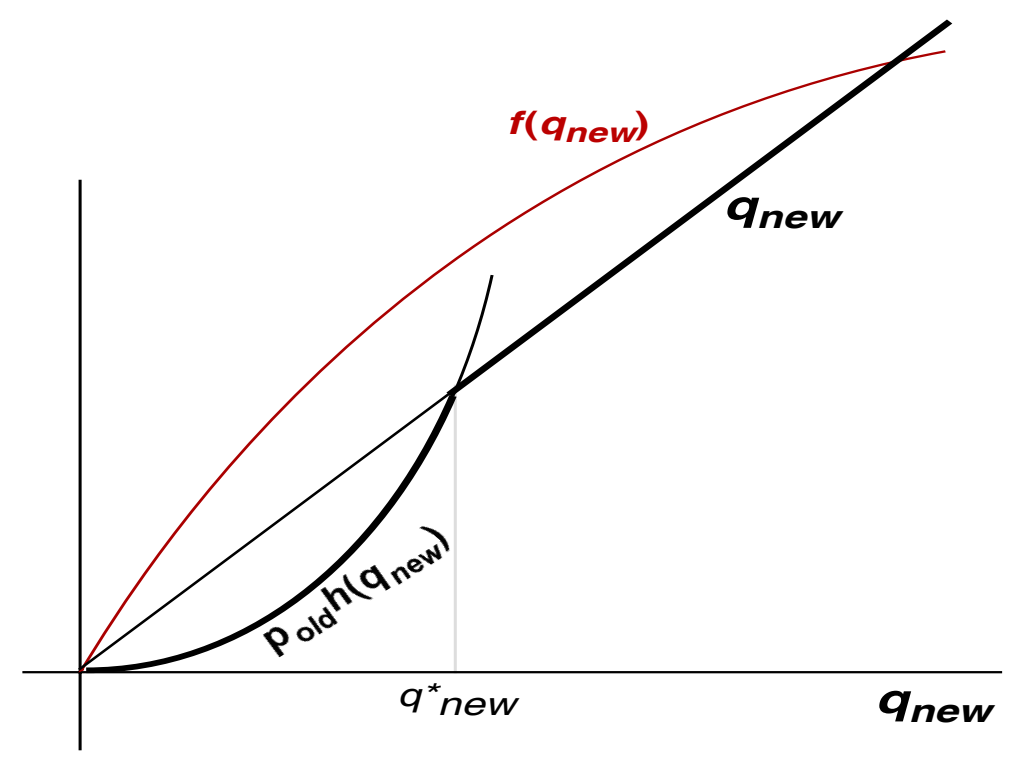

FIGURE 1: Combined cost and revenue functions of new and old technologies.

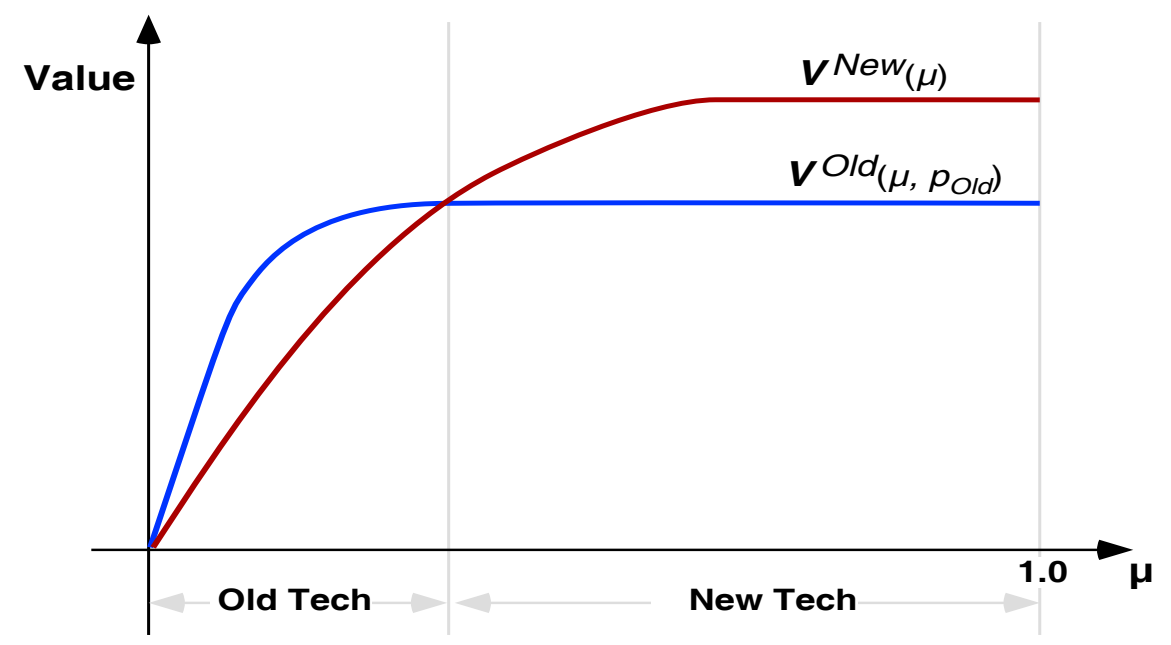

FIGURE 2: New and old technology value functions. 


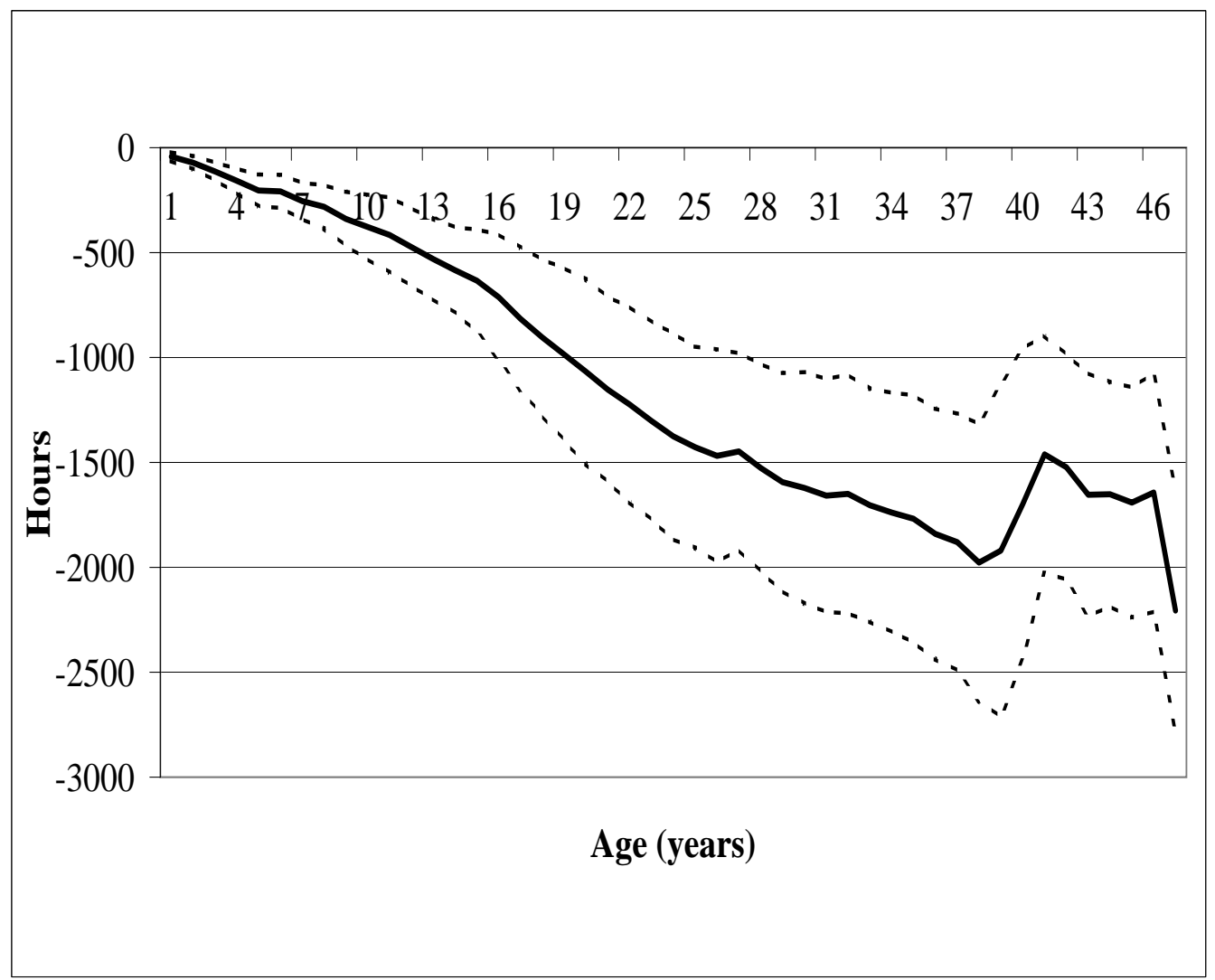

FIGURE 3: Annual hourly utilization as a function of aircraft age. Regression coefficients are calculated using year and aircraft-type fixed effects. $95 \%$ confidence intervals are calculated using standard errors that are clustered by aircraft type. 


\section{Table $1:$
Summary Statistics}

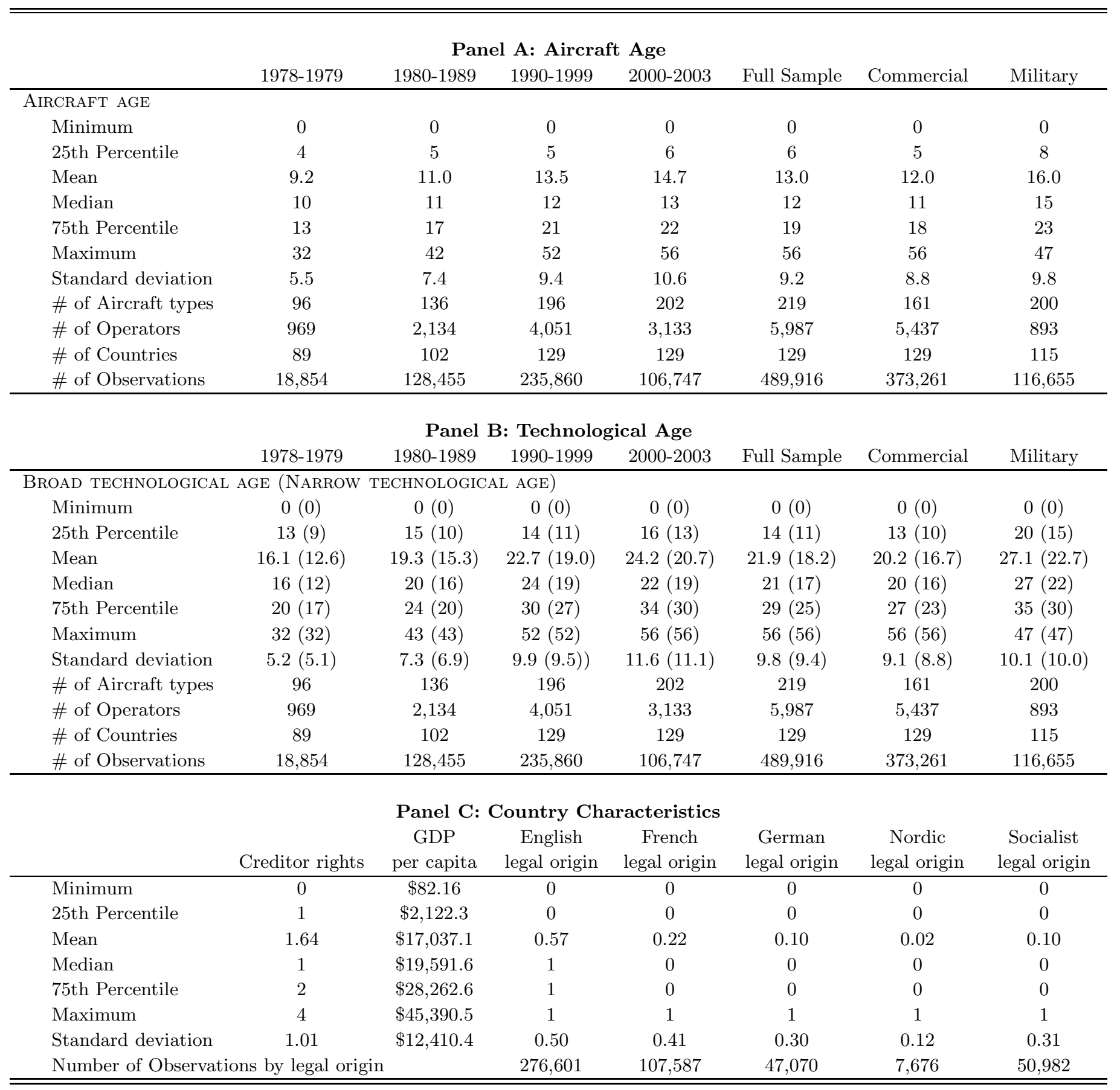

This table reports summary statistics for aircraft age, technological age (broad and narrow), and country characteristics. The summary statistics for aircraft age are reported for the periods 1978-1979, 1980-1989, 1990-1999, 2000-2003, as well as for the entire period. The table also reports summary statistics separately for commercial and military aircraft. 
Table 2:

Aircraft Vintage and Usage

\begin{tabular}{|c|c|c|c|c|c|c|}
\hline $\begin{array}{l}\text { Dependent } \\
\text { Variable= }\end{array}$ & $\begin{array}{c}\text { Hours } \\
\text { (per year) }\end{array}$ & $\begin{array}{c}\text { Hours } \\
\text { (per year) }\end{array}$ & $\begin{array}{c}\text { Hours } \\
\text { (per year) }\end{array}$ & $\begin{array}{c}\text { Hours } \\
\text { (per year) }\end{array}$ & $\begin{array}{c}\text { Hours } \\
\text { (per year) }\end{array}$ & $\begin{array}{c}\text { Hours } \\
\text { (per year) }\end{array}$ \\
\hline Age & $\begin{array}{c}-57.61 \mathrm{a} \\
(6.219)\end{array}$ & $\begin{array}{c}-57.54 \mathrm{a} \\
(6.207)\end{array}$ & $\begin{array}{c}-4.287 \\
(29.662)\end{array}$ & & & \\
\hline $\begin{array}{l}\text { Tech Age } \\
\text { (broad) }\end{array}$ & & & & $\begin{array}{c}-31.964 b \\
(13.799)\end{array}$ & $\begin{array}{c}-31.896 \mathrm{~b} \\
(13.763)\end{array}$ & $\begin{array}{c}27.010 \\
(23.422)\end{array}$ \\
\hline Jet Fuel & & $\begin{array}{c}84.456 \\
(63.858)\end{array}$ & $\begin{array}{c}276.341 \mathrm{~b} \\
(137.546)\end{array}$ & & $\begin{array}{l}119.151 \\
(72.515)\end{array}$ & $\begin{array}{c}330.397 \mathrm{a} \\
(95.056)\end{array}$ \\
\hline Age $\times$ Jet Fuel & & & $\begin{array}{c}-11.951 \mathrm{c} \\
(6.407)\end{array}$ & & & \\
\hline Tech Age $\times$ Jet Fuel & & & & & & $\begin{array}{c}-18.457 \mathrm{a} \\
(4.726)\end{array}$ \\
\hline \multicolumn{7}{|l|}{ Fixed-Effects } \\
\hline Year & Yes & No & Yes & Yes & No & Yes \\
\hline \# of Aircraft Types & 76 & 76 & 76 & 76 & 76 & 76 \\
\hline \# of Aircraft & 25,009 & 25,009 & 25,009 & 25,009 & 25,009 & 25,009 \\
\hline Adjusted $R^{2}$ & 0.20 & 0.20 & 0.23 & 0.09 & 0.09 & 0.22 \\
\hline Observations & 179,836 & 179,836 & 179,836 & 179,836 & 179,836 & 179,836 \\
\hline
\end{tabular}

The dependent variable is aircraft yearly usage in hours. Age is the age of the aircraft. Tech Age is the technological age of the aircraft. Jet Fuel is the logarithm of the average annual jet fuel price. All regressions include an intercept (not reported). Standard-errors, reported in parenthesis, are clustered by aircraft type. 
Table 3:

\section{Creditor Rights and Aircraft Vintage}

\begin{tabular}{|c|c|c|c|c|c|c|c|c|c|}
\hline $\begin{array}{l}\text { Dependent } \\
\text { Variable= }\end{array}$ & Age & Age & Age & $\begin{array}{c}\text { Tech Age } \\
\text { (broad) }\end{array}$ & $\begin{array}{c}\text { Tech Age } \\
\text { (broad) }\end{array}$ & $\begin{array}{c}\text { Tech Age } \\
\text { (broad) }\end{array}$ & $\begin{array}{l}\text { Tech Age } \\
\text { (narrow) }\end{array}$ & $\begin{array}{l}\text { Tech Age } \\
\text { (narrow) }\end{array}$ & $\begin{array}{l}\text { Tech Age } \\
\text { (narrow) }\end{array}$ \\
\hline GDP & $\begin{array}{c}0.021 \\
(0.150)\end{array}$ & $\begin{array}{c}0.125 \\
(0.162)\end{array}$ & $\begin{array}{c}0.094 \\
(0.142)\end{array}$ & $\begin{array}{c}0.007 \\
(0.144)\end{array}$ & $\begin{array}{c}0.124 \\
(0.142)\end{array}$ & $\begin{array}{c}0.075 \\
(0.156)\end{array}$ & $\begin{array}{l}-0.039 \\
(0.122)\end{array}$ & $\begin{array}{c}0.037 \\
(0.134)\end{array}$ & $\begin{array}{c}0.054 \\
(0.138)\end{array}$ \\
\hline GDP growth & $\begin{array}{l}-0.056 \\
(0.061)\end{array}$ & $\begin{array}{c}0.090 \mathrm{a} \\
(0.032)\end{array}$ & $\begin{array}{l}0.056 \mathrm{c} \\
(0.031)\end{array}$ & $\begin{array}{c}0.005 \\
(0.048)\end{array}$ & $\begin{array}{c}0.073 \mathrm{a} \\
(0.031)\end{array}$ & $\begin{array}{l}0.050 \mathrm{c} \\
(0.027)\end{array}$ & $\begin{array}{l}-0.038 \\
(0.045)\end{array}$ & $\begin{array}{l}0.073 \mathrm{a} \\
(0.027)\end{array}$ & $\begin{array}{c}0.049 \mathrm{~b} \\
(0.024)\end{array}$ \\
\hline GDP per capita & $\begin{array}{c}-0.476 \mathrm{c} \\
(0.242)\end{array}$ & $\begin{array}{c}-2.245 \mathrm{a} \\
(0.571)\end{array}$ & $\begin{array}{c}-1.444 \mathrm{c} \\
(0.862)\end{array}$ & $\begin{array}{c}-0.806 \mathrm{a} \\
(0.284)\end{array}$ & $\begin{array}{c}-1.890 \mathrm{a} \\
(0.583)\end{array}$ & $\begin{array}{c}-1.263 \mathrm{c} \\
(0.710)\end{array}$ & $\begin{array}{c}-0.917 \mathrm{a} \\
(0.212)\end{array}$ & $\begin{array}{c}-2.719 \mathrm{a} \\
(0.581)\end{array}$ & $\begin{array}{c}-1.681 \mathrm{~b} \\
(0.774)\end{array}$ \\
\hline $\begin{array}{l}\text { GDP per } \\
\text { capita growth }\end{array}$ & $\begin{array}{c}0.095 \mathrm{~b} \\
(0.048)\end{array}$ & $\begin{array}{l}0.053 \mathrm{a} \\
(0.020)\end{array}$ & $\begin{array}{c}0.050 \mathrm{a} \\
(0.020)\end{array}$ & $\begin{array}{c}0.025 \\
(0.027)\end{array}$ & $\begin{array}{l}0.039 \mathrm{a} \\
(0.016)\end{array}$ & $\begin{array}{l}0.031 \mathrm{~b} \\
(0.014)\end{array}$ & $\begin{array}{c}0.069 \mathrm{~b} \\
(0.029)\end{array}$ & $\begin{array}{l}0.042 \mathrm{a} \\
(0.014)\end{array}$ & $\begin{array}{l}0.037 \mathrm{a} \\
(0.012)\end{array}$ \\
\hline Population & $\begin{array}{c}-0.531 \mathrm{~b} \\
(0.258)\end{array}$ & $\begin{array}{c}10.610 \mathrm{a} \\
(2.005)\end{array}$ & $\begin{array}{l}2.959 \mathrm{~b} \\
(1.352)\end{array}$ & $\begin{array}{c}-0.647 \mathrm{c} \\
(0.330)\end{array}$ & $\begin{array}{l}8.366 \mathrm{a} \\
(2.208)\end{array}$ & $\begin{array}{c}1.567 \\
(1.279)\end{array}$ & $\begin{array}{c}-0.511 \mathrm{c} \\
(0.263)\end{array}$ & $\begin{array}{l}7.851 \mathrm{a} \\
(2.092)\end{array}$ & $\begin{array}{c}1.776 \\
(1.369)\end{array}$ \\
\hline Area & $\begin{array}{c}0.362 \\
(0.211)\end{array}$ & $\begin{array}{c}6.993 \\
(5.497)\end{array}$ & $\begin{array}{l}-0.483 \\
(1.317)\end{array}$ & $\begin{array}{c}0.398 \\
(0.245)\end{array}$ & $\begin{array}{c}-17.035 \mathrm{a} \\
(4.659)\end{array}$ & $\begin{array}{c}0.530 \\
(1.082)\end{array}$ & $\begin{array}{l}0.413 \mathrm{c} \\
(0.225)\end{array}$ & $\begin{array}{l}-2.330 \\
(4.477)\end{array}$ & $\begin{array}{c}0.303 \\
(1.234)\end{array}$ \\
\hline Creditor rights & $\begin{array}{c}-0.446 \mathrm{~b} \\
(0.218)\end{array}$ & $\begin{array}{c}-0.791 \mathrm{~b} \\
(0.339)\end{array}$ & $\begin{array}{c}-0.668 \mathrm{~b} \\
(0.305)\end{array}$ & $\begin{array}{c}-0.395 \mathrm{c} \\
(0.232)\end{array}$ & $\begin{array}{c}-0.696 \mathrm{~b} \\
(0.302)\end{array}$ & $\begin{array}{c}-0.443 \mathrm{c} \\
(0.257)\end{array}$ & $\begin{array}{c}-0.548 \mathrm{~b} \\
(0.229)\end{array}$ & $\begin{array}{c}-0.527 \mathrm{c} \\
(0.301)\end{array}$ & $\begin{array}{l}-0.301 \\
(0.285)\end{array}$ \\
\hline \multicolumn{10}{|l|}{ Fixed-Effects } \\
\hline Year & Yes & Yes & Yes & Yes & Yes & Yes & Yes & Yes & Yes \\
\hline Country & No & Yes & No & No & Yes & No & No & Yes & No \\
\hline Operator & No & No & Yes & No & No & Yes & No & No & Yes \\
\hline \# of Countries & 129 & 129 & 129 & 129 & 129 & 129 & 129 & 129 & 129 \\
\hline \# of Operators & 5,883 & 5,883 & 5,883 & 5,883 & 5,883 & 5,883 & 5,883 & 5,883 & 5,883 \\
\hline Adjusted $R^{2}$ & 0.09 & 0.12 & 0.45 & 0.11 & 0.15 & 0.51 & 0.15 & 0.18 & 0.51 \\
\hline Observations & 489,407 & 489,407 & 489,407 & 489,407 & 489,407 & 489,407 & 489,407 & 489,407 & 489,407 \\
\hline
\end{tabular}

The dependent variable is aircraft age (columns 1-3), broad technological age (columns 4-6), and narrow technological age (columns 7-9). GDP is the natural logarithm of real GDP, GDP growth is the annual growth rate of GDP, GDP per capita is the natural logarithm of real GDP per capita, GDP per capita growth is the annual growth rate of GDP per capita. Population is the natural logarithm of the population. Area is the natural logarithm of the country surface in sq. km. Creditor rights is an index aggregating creditor rights, following Djankov et al. (2007). The index ranges from 0 (weak creditor rights) to 4 (strong creditor rights) and is constructed as of January for every year from 1978 to 2003. Columns without country or operator fixed effects also include dummies for French legal origin, German legal origin, Nordic legal origin, and Socialist legal origin (not reported for brevity). All regressions include an intercept (not reported) and year fixed effects. Standard-errors are clustered by country and reported in parentheses. a, b and c denote statistical significance at the $1 \%, 5 \%$, and $10 \%$ levels, respectively. 
Table 4:

Creditor Rights and Aircraft Age: Commercial Vs. Military Aircraft

\begin{tabular}{|c|c|c|c|c|c|c|}
\hline & $\begin{array}{c}\text { Commercial } \\
\text { Age }\end{array}$ & $\begin{array}{c}\text { Military } \\
\text { Age }\end{array}$ & $\begin{array}{c}\text { Commercial } \\
\text { Age }\end{array}$ & $\begin{array}{c}\text { Military } \\
\text { Age }\end{array}$ & $\begin{array}{c}\text { Commercial } \\
\text { Age }\end{array}$ & $\begin{array}{c}\text { Military } \\
\text { Age }\end{array}$ \\
\hline GDP & $\begin{array}{c}0.180 \\
(0.387)\end{array}$ & $\begin{array}{l}-0.153 \\
(0.147)\end{array}$ & $\begin{array}{c}0.242 \\
(0.154)\end{array}$ & $\begin{array}{l}-0.064 \\
(0.153)\end{array}$ & $\begin{array}{c}0.142 \\
(0.115)\end{array}$ & $\begin{array}{l}-0.038 \\
(0.173)\end{array}$ \\
\hline GDP growth & $\begin{array}{c}-0.059 \\
(0.053)\end{array}$ & $\begin{array}{l}-0.206 \\
(0.164)\end{array}$ & $\begin{array}{l}0.092 \mathrm{a} \\
(0.026)\end{array}$ & $\begin{array}{c}-0.132 \mathrm{c} \\
(0.068)\end{array}$ & $\begin{array}{l}0.058 \mathrm{a} \\
(0.020)\end{array}$ & $\begin{array}{r}-0.150 \mathrm{~b} \\
(0.070)\end{array}$ \\
\hline GDP per capita & $\begin{array}{c}-0.756 \mathrm{c} \\
(0.387)\end{array}$ & $\begin{array}{l}1.464 \mathrm{a} \\
(0.353)\end{array}$ & $\begin{array}{c}-2.390 \mathrm{a} \\
(0.623)\end{array}$ & $\begin{array}{c}1.056 \\
(1.189)\end{array}$ & $\begin{array}{c}-1.815 \mathrm{a} \\
(0.640)\end{array}$ & $\begin{array}{c}1.003 \\
(1.293)\end{array}$ \\
\hline GDP per capita growth & $\begin{array}{c}0.059 \mathrm{~b} \\
(0.029)\end{array}$ & $\begin{array}{l}0.284 \mathrm{c} \\
(0.166)\end{array}$ & $\begin{array}{l}0.032 \mathrm{a} \\
(0.011)\end{array}$ & $\begin{array}{l}0.167 \mathrm{a} \\
(0.065)\end{array}$ & $\begin{array}{l}0.030 \mathrm{a} \\
(0.010)\end{array}$ & $\begin{array}{l}0.178 \mathrm{a} \\
(0.067)\end{array}$ \\
\hline Population & $\begin{array}{c}-0.919 \mathrm{a} \\
(0.289)\end{array}$ & $\begin{array}{l}-0.254 \\
(0.343)\end{array}$ & $\begin{array}{l}9.251 \mathrm{a} \\
(2.361)\end{array}$ & $\begin{array}{c}1.732 \\
(4.402)\end{array}$ & $\begin{array}{c}1.800 \\
(1.395)\end{array}$ & $\begin{array}{c}2.381 \\
(4.488)\end{array}$ \\
\hline Area & $\begin{array}{l}0.546 \mathrm{~b} \\
(0.255)\end{array}$ & $\begin{array}{c}0.071 \\
(0.249)\end{array}$ & $\begin{array}{c}2.611 \\
(5.878)\end{array}$ & $\begin{array}{l}83.003 \mathrm{~b} \\
(37.051)\end{array}$ & $\begin{array}{c}0.857 \\
(1.126)\end{array}$ & $\begin{array}{l}-9.820 \\
(6.390)\end{array}$ \\
\hline Airforce size & $\begin{array}{l}-0.177 \\
(0.389)\end{array}$ & $\begin{array}{c}-1.160 \mathrm{~b} \\
(0.453)\end{array}$ & $\begin{array}{c}-0.774 \mathrm{c} \\
(0.413)\end{array}$ & $\begin{array}{c}-5.538 \mathrm{a} \\
(0.863)\end{array}$ & $\begin{array}{c}-0.986 \mathrm{~b} \\
(0.412)\end{array}$ & $\begin{array}{r}-5.100 \mathrm{a} \\
(0.972)\end{array}$ \\
\hline Creditor rights & $\begin{array}{c}-0.512 \mathrm{~b} \\
(0.240)\end{array}$ & $\begin{array}{l}-0.351 \\
(0.409)\end{array}$ & $\begin{array}{c}-0.731 \mathrm{c} \\
(0.412)\end{array}$ & $\begin{array}{l}-0.293 \\
(0.597)\end{array}$ & $\begin{array}{c}-0.619 \mathrm{~b} \\
(0.312)\end{array}$ & $\begin{array}{l}-0.490 \\
(0.646)\end{array}$ \\
\hline \multicolumn{7}{|l|}{ Fixed-Effects } \\
\hline Year & Yes & Yes & Yes & Yes & Yes & Yes \\
\hline Country & No & No & Yes & Yes & No & No \\
\hline Operator & No & No & No & No & Yes & Yes \\
\hline \# of Countries & 129 & 114 & 129 & 114 & 129 & 114 \\
\hline \# of Operators & 5,435 & 733 & 5,435 & 733 & 5,435 & 733 \\
\hline Adjusted $R^{2}$ & 0.10 & 0.15 & 0.14 & 0.20 & 0.49 & 0.32 \\
\hline Observations & 372,897 & 116,510 & 372,897 & 116,510 & 372,897 & 116,510 \\
\hline
\end{tabular}

The dependent variable is aircraft age of either commercial or military aircraft. GDP is the natural logarithm of real GDP, GDP growth is the annual growth rate of GDP, GDP per capita is the natural logarithm of real GDP per capita, GDP per capita growth is the annual growth rate of GDP per capita. Population is the natural logarithm of the population. Area is the natural logarithm of the country surface in sq. $\mathrm{km}$. Airforce size is the fraction of military aircraft as a percentage of all aircraft in a country. Creditor rights is an index aggregating creditor rights, following Djankov et al. (2007). The index ranges from 0 (weak creditor rights) to 4 (strong creditor rights) and is constructed as of January for every year from 1978 to 2003. The first two columns also include dummies for French legal origin, German legal origin, Nordic legal origin, and Socialist legal origin (not reported for brevity). All regressions include an intercept (not reported) and year fixed effects. Standard-errors are clustered by country and reported in parentheses. a, b and c denote statistical significance at the $1 \%, 5 \%$, and $10 \%$ levels, respectively. 
Table 5:

\section{Creditor Rights and Technological Äge: Commercial Vs. Military Aircraft}

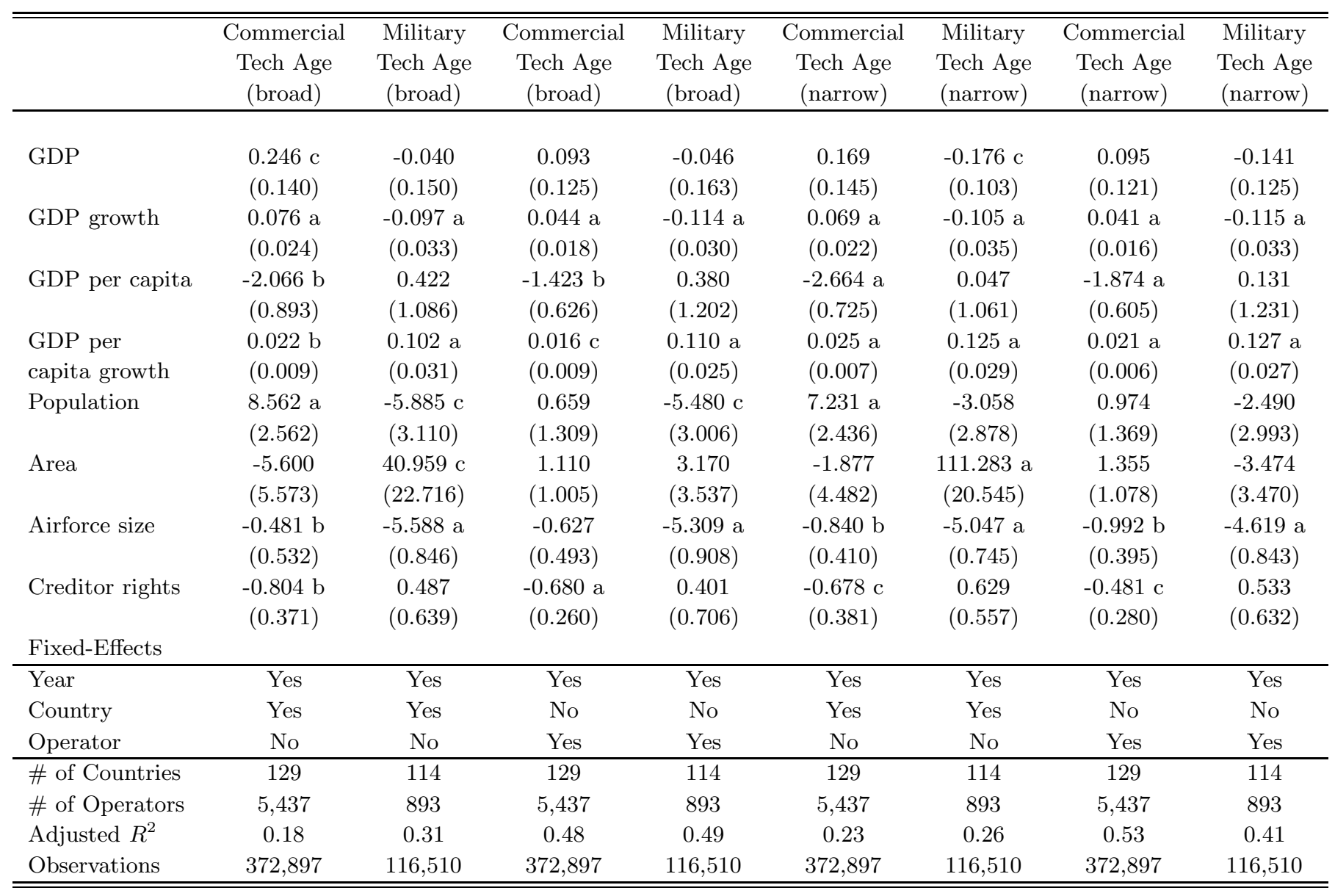

The dependent variable is the broad technological age (columns 1-4), or narrow technological age (columns 5-8) of either commercial or military aircraft. GDP is the natural logarithm of real GDP, GDP growth is the annual growth rate of GDP, GDP per capita is the natural logarithm of real GDP per capita, GDP per capita growth is the annual growth rate of GDP per capita. Population is the natural logarithm of the population. Area is the natural logarithm of the country surface in sq. km. Airforce size is the fraction of military aircraft as a percentage of all aircraft in a country. Creditor rights is an index aggregating creditor rights, following Djankov et al. (2007). The index ranges from 0 (weak creditor rights) to 4 (strong creditor rights) and is constructed as of January for every year from 1978 to 2003. All regressions include an intercept (not reported) and year fixed effects. Standard-errors are clustered by country and reported in parentheses. a, b and c denote statistical significance at the $1 \%, 5 \%$, and $10 \%$ levels, respectively. 
Table 6:

Creditor Rights and Age: Leased Vs. Non-Leased Aircraft

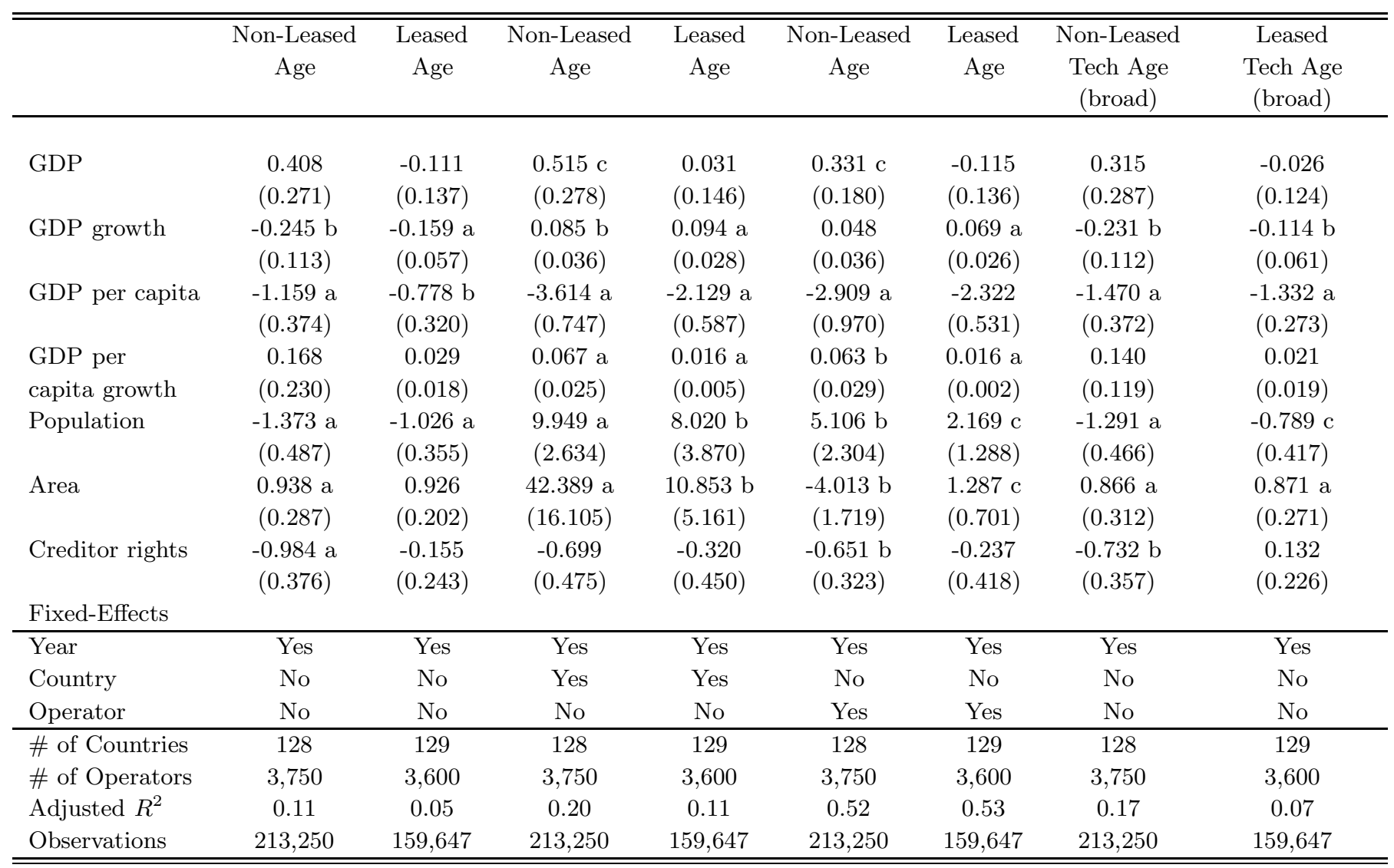

The dependent variable is aircraft age or broad technological age of either non-leased or leased aircraft. GDP is the natural logarithm of real GDP, GDP growth is the annual growth rate of GDP, GDP per capita is the natural logarithm of real GDP per capita, GDP per capita growth is the annual growth rate of GDP per capita. Population is the natural logarithm of the population. Area is the natural logarithm of the country surface in sq. km. Creditor rights is an index aggregating creditor rights, following Djankov et al. (2007). The index ranges from 0 (weak creditor rights) to 4 (strong creditor rights) and is constructed as of January for every year from 1978 to 2003. Columns without country or operator fixed effects also include dummies for French legal origin, German legal origin, Nordic legal origin, and Socialist legal origin (not reported for brevity). All regressions include an intercept (not reported) and year fixed effects. Standard-errors are clustered by country and reported in parentheses. a, b and c denote statistical significance at the $1 \%, 5 \%$, and $10 \%$ levels, respectively. 
Table 7:

Creditor Rights and Age of Non-Leased Aircraft: Poor Vs. Rich Countries

\begin{tabular}{|c|c|c|c|c|c|c|c|c|c|}
\hline & Rich & Poor & Rich & Poor & Rich & Poor & $\begin{array}{c}\text { Rich } \\
\text { (U.S. } \\
\text { Excluded) }\end{array}$ & Rich & Poor \\
\hline & Age & Age & Age & Age & Age & Age & Age & Age & Age \\
\hline GDP & $\begin{array}{l}0.483 \mathrm{c} \\
(0.274)\end{array}$ & $\begin{array}{l}0.351 \mathrm{a} \\
(0.132)\end{array}$ & $\begin{array}{l}0.655 \mathrm{a} \\
(0.250)\end{array}$ & $\begin{array}{c}0.014 \\
(0.112)\end{array}$ & $\begin{array}{l}0.368 \mathrm{c} \\
(0.189)\end{array}$ & $\begin{array}{c}0.148 \\
(0.115)\end{array}$ & $\begin{array}{l}-0.233 \\
(0.316)\end{array}$ & $\begin{array}{c}0.577 \\
(0.372)\end{array}$ & $\begin{array}{c}0.129 \\
(0.168)\end{array}$ \\
\hline GDP growth & $\begin{array}{c}-0.033 \mathrm{~b} \\
(0.091)\end{array}$ & $\begin{array}{l}-0.136 \\
(0.264)\end{array}$ & $\begin{array}{c}0.085 \mathrm{~b} \\
(0.039)\end{array}$ & $\begin{array}{l}0.268 \mathrm{c} \\
(0.159)\end{array}$ & $\begin{array}{c}0.063 \\
(0.039)\end{array}$ & $\begin{array}{c}0.220 \\
(0.142)\end{array}$ & $\begin{array}{l}0.061 \mathrm{c} \\
(0.034)\end{array}$ & $\begin{array}{c}0.019 \\
(0.099)\end{array}$ & $\begin{array}{c}1.583 \\
(1.143)\end{array}$ \\
\hline GDP per capita & $\begin{array}{c}-1.805 \mathrm{a} \\
(0.329)\end{array}$ & $\begin{array}{l}-1.553 \\
(1.037)\end{array}$ & $\begin{array}{c}-4.579 \mathrm{a} \\
(1.620)\end{array}$ & $\begin{array}{c}-3.380 \mathrm{a} \\
(0.735)\end{array}$ & $\begin{array}{c}-5.005 \mathrm{a} \\
(1.677)\end{array}$ & $\begin{array}{c}-2.695 \mathrm{a} \\
(0.427)\end{array}$ & $\begin{array}{c}-4.354 \mathrm{a} \\
(1.534)\end{array}$ & $\begin{array}{c}-2.625 \mathrm{~b} \\
(1.222)\end{array}$ & $\begin{array}{l}-0.889 \\
(2.184)\end{array}$ \\
\hline $\begin{array}{l}\text { GDP per } \\
\text { capita growth }\end{array}$ & $\begin{array}{c}0.106 \\
(0.087)\end{array}$ & $\begin{array}{c}0.042 \\
(0.286)\end{array}$ & $\begin{array}{l}0.064 \mathrm{a} \\
(0.024)\end{array}$ & $\begin{array}{l}-0.186 \\
(0.162)\end{array}$ & $\begin{array}{l}0.056 \mathrm{~b} \\
(0.027)\end{array}$ & $\begin{array}{l}-0.168 \\
(0.143)\end{array}$ & $\begin{array}{l}0.066 \mathrm{~b} \\
(0.026)\end{array}$ & $\begin{array}{l}-0.009 \\
(0.041)\end{array}$ & $\begin{array}{l}-1.602 \\
(1.195)\end{array}$ \\
\hline Population & $\begin{array}{c}-0.453 \mathrm{a} \\
(0.447)\end{array}$ & $\begin{array}{c}-2.118 \mathrm{a} \\
(0.515)\end{array}$ & $\begin{array}{l}9.023 \mathrm{a} \\
(2.896)\end{array}$ & $\begin{array}{c}0.370 \\
(6.180)\end{array}$ & $\begin{array}{c}2.743 \\
(2.031)\end{array}$ & $\begin{array}{l}-0.869 \\
(4.260)\end{array}$ & $\begin{array}{c}10.043 \mathrm{a} \\
(2.949)\end{array}$ & $\begin{array}{l}-0.579 \\
(0.600)\end{array}$ & $\begin{array}{l}-0.729 \\
(1.017)\end{array}$ \\
\hline Area & $\begin{array}{l}0.762 \mathrm{a} \\
(0.252)\end{array}$ & $\begin{array}{c}0.117 \\
(0.522)\end{array}$ & $\begin{array}{l}47.645 \mathrm{a} \\
(14.562)\end{array}$ & $\begin{array}{c}-731.985 \mathrm{~b} \\
(336.94)\end{array}$ & $\begin{array}{l}-2.274 \\
(1.418)\end{array}$ & $\begin{array}{c}-1.904 \mathrm{c} \\
(3.924)\end{array}$ & $\begin{array}{l}44.943 \mathrm{a} \\
(16.585)\end{array}$ & $\begin{array}{c}0.884 \mathrm{~b} \\
(0.353)\end{array}$ & $\begin{array}{l}-2.007 \\
(1.893)\end{array}$ \\
\hline Creditor rights & $\begin{array}{c}-0.715 \mathrm{~b} \\
(0.355)\end{array}$ & $\begin{array}{c}0.172 \\
(0.460)\end{array}$ & $\begin{array}{c}-1.017 \mathrm{a} \\
(0.335)\end{array}$ & $\begin{array}{l}-0.025 \\
(0.634)\end{array}$ & $\begin{array}{c}-0.648 \mathrm{~b} \\
(0.311)\end{array}$ & $\begin{array}{c}0.345 \\
(0.548)\end{array}$ & $\begin{array}{c}-0.941 \mathrm{a} \\
(0.348)\end{array}$ & $\begin{array}{c}-0.803 \mathrm{~b} \\
(0.403)\end{array}$ & $\begin{array}{c}0.489 \\
(0.400)\end{array}$ \\
\hline Enforcement & & & & & & & & $\begin{array}{c}0.893 \\
(0.643)\end{array}$ & $\begin{array}{c}-3.904 \mathrm{c} \\
(2.258)\end{array}$ \\
\hline \multicolumn{10}{|l|}{ Fixed-Effects } \\
\hline Year & Yes & Yes & Yes & Yes & Yes & Yes & Yes & Yes & Yes \\
\hline Country & No & No & Yes & Yes & No & No & Yes & No & No \\
\hline Operator & No & No & No & No & Yes & Yes & No & No & No \\
\hline \# of Countries & 66 & 72 & 66 & 72 & 66 & 72 & 65 & 37 & 15 \\
\hline \# of Operators & 2,963 & 845 & 2,963 & 845 & 2,963 & 845 & 2,093 & 1,649 & 269 \\
\hline Adjusted $R^{2}$ & 0.12 & 0.26 & 0.16 & 0.37 & 0.51 & 0.58 & 0.25 & 0.08 & 0.36 \\
\hline Observations & 177,937 & 35,313 & 177,937 & 35,313 & 177,937 & 35,313 & 106,027 & 86,058 & 13,492 \\
\hline
\end{tabular}

The dependent variable is aircraft age in either rich or poor countries. Rich (poor) countries are defined in each year as those with GDP per capita greater (smaller) than the sample median of that year. GDP is the natural logarithm of real GDP, GDP growth is the annual growth rate of GDP, GDP per capita is the natural logarithm of real GDP per capita, GDP per capita growth is the annual growth rate of GDP per capita. Population is the natural logarithm of the population. Area is the natural logarithm of the country surface in sq. $\mathrm{km}$. Creditor rights is an index aggregating creditor rights, following Djankov et al. (2007). The index ranges from 0 (weak creditor rights) to 4 (strong creditor rights) and is constructed as of January for every year from 1978 to 2003. Columns without country or operator fixed effects also include dummies for French legal origin, German legal origin, Nordic legal origin, and Socialist legal origin (not reported for brevity). All regressions include an intercept (not reported) and year fixed effects. Standard-errors are clustered by country and reported in parentheses. a, b and c denote statistical significance at the $1 \%, 5 \%$, and $10 \%$ levels, respectively. 


\section{Table 8:}

\begin{tabular}{|c|c|c|c|c|c|c|c|c|}
\hline & $\begin{array}{c}\text { Non-Leased } \\
\text { Age }\end{array}$ & $\begin{array}{c}\text { Leased } \\
\text { Age }\end{array}$ & $\begin{array}{c}\text { Non-Leased } \\
\text { Age }\end{array}$ & $\begin{array}{c}\text { Leased } \\
\text { Age }\end{array}$ & $\begin{array}{c}\text { Non-Leased } \\
\text { Age }\end{array}$ & $\begin{array}{c}\text { Leased } \\
\text { Age }\end{array}$ & $\begin{array}{c}\text { Non-Leased } \\
\text { Tech Age } \\
\text { (broad) }\end{array}$ & $\begin{array}{c}\text { Leased } \\
\text { Tech Age } \\
\text { (broad) }\end{array}$ \\
\hline GDP & $\begin{array}{c}0.384 \\
(0.270)\end{array}$ & $\begin{array}{l}-0.122 \\
(0.131)\end{array}$ & $\begin{array}{l}0.511 \mathrm{c} \\
(0.274)\end{array}$ & $\begin{array}{c}0.021 \\
(0.143)\end{array}$ & $\begin{array}{l}0.330 \mathrm{c} \\
(0.178)\end{array}$ & $\begin{array}{l}-0.113 \\
(0.138)\end{array}$ & $\begin{array}{c}0.294 \\
(0.286)\end{array}$ & $\begin{array}{l}-0.036 \\
(0.120)\end{array}$ \\
\hline GDP growth & $\begin{array}{c}-0.203 \mathrm{~b} \\
(0.102)\end{array}$ & $\begin{array}{c}-0.144 \mathrm{~b} \\
(0.055)\end{array}$ & $\begin{array}{l}0.084 \mathrm{~b} \\
(0.037)\end{array}$ & $\begin{array}{c}0.097 \mathrm{a} \\
(0.028)\end{array}$ & $\begin{array}{c}0.048 \\
(0.036)\end{array}$ & $\begin{array}{l}0.069 \mathrm{a} \\
(0.026)\end{array}$ & $\begin{array}{c}-0.196 \mathrm{c} \\
(0.104)\end{array}$ & $\begin{array}{c}-0.139 \mathrm{~b} \\
(0.058)\end{array}$ \\
\hline $\begin{array}{l}\text { GDP per } \\
\text { capita growth }\end{array}$ & $\begin{array}{c}0.128 \\
(0.101)\end{array}$ & $\begin{array}{l}0.029 \mathrm{c} \\
(0.016)\end{array}$ & $\begin{array}{l}0.064 \mathrm{a} \\
(0.024)\end{array}$ & $\begin{array}{c}0.015 \mathrm{a} \\
(0.004)\end{array}$ & $\begin{array}{l}0.063 \mathrm{~b} \\
(0.029)\end{array}$ & $\begin{array}{l}0.016 \mathrm{a} \\
(0.002)\end{array}$ & $\begin{array}{c}0.106 \\
(0.105)\end{array}$ & $\begin{array}{c}0.021 \\
(0.018)\end{array}$ \\
\hline Population & $\begin{array}{c}-1.398 \mathrm{a} \\
(0.495)\end{array}$ & $\begin{array}{c}-1.074 \mathrm{a} \\
(0.340)\end{array}$ & $\begin{array}{c}10.134 \mathrm{a} \\
(2.780)\end{array}$ & $\begin{array}{l}7.614 \mathrm{c} \\
(3.959)\end{array}$ & $\begin{array}{l}4.790 \mathrm{~b} \\
(2.226)\end{array}$ & $\begin{array}{l}2.174 \mathrm{c} \\
(1.288)\end{array}$ & $\begin{array}{c}-1.312 \mathrm{a} \\
(0.469)\end{array}$ & $\begin{array}{c}-0.833 \mathrm{~b} \\
(0.407)\end{array}$ \\
\hline Creditor rights & $\begin{array}{c}-1.067 \mathrm{a} \\
(0.357)\end{array}$ & $\begin{array}{l}-0.297 \\
(0.236)\end{array}$ & $\begin{array}{l}-0.704 \\
(0.490)\end{array}$ & $\begin{array}{l}-0.282 \\
(0.440)\end{array}$ & $\begin{array}{c}-0.619 \mathrm{~b} \\
(0.298)\end{array}$ & $\begin{array}{l}-0.249 \\
(0.404)\end{array}$ & $\begin{array}{c}-0.801 \mathrm{~b} \\
(0.339)\end{array}$ & $\begin{array}{l}0.0001 \\
(0.218)\end{array}$ \\
\hline \multicolumn{9}{|l|}{ Fixed-Effects } \\
\hline Year & Yes & Yes & Yes & Yes & Yes & Yes & Yes & Yes \\
\hline Country & No & No & Yes & Yes & No & No & No & No \\
\hline Operator & No & No & No & No & Yes & Yes & No & No \\
\hline \# of Countries & 128 & 129 & 128 & 129 & 128 & 129 & 128 & 129 \\
\hline \# of Operators & 3,750 & 3,600 & 3,750 & 3,600 & 3,750 & 3,600 & 3,750 & 3,600 \\
\hline Adjusted $R^{2}$ & 0.13 & 0.06 & 0.20 & 0.11 & 0.52 & 0.53 & 0.18 & 0.07 \\
\hline Observations & 213,250 & 159,647 & 213,250 & 159,647 & 213,250 & 159,647 & 213,250 & 159,647 \\
\hline
\end{tabular}

The dependent variable is aircraft age or broad technological age in either non-leased or leased aircraft. GDP is the natural logarithm of real GDP, GDP growth is the annual growth rate of GDP, GDP per capita is the natural logarithm of real GDP per capita, GDP per capita growth is the annual growth rate of GDP per capita. Population is the natural logarithm of the population. Area is the natural logarithm of the country surface in sq. $\mathrm{km}$. Government is a dummy variable that equals one if the airline operating the aircraft is at least partially owned by the government and equals zero otherwise. Creditor rights is an index aggregating creditor rights, following Djankov et al. (2007). The index ranges from 0 (weak creditor rights) to 4 (strong creditor rights) and is constructed as of January for every year from 1978 to 2003. Columns without country or operator fixed effects also include dummies for French legal origin, German legal origin, Nordic legal origin, and Socialist legal origin (not reported for brevity). All regressions include an intercept (not reported) and year fixed effects. Standard-errors are clustered by country and reported in parentheses. a, b and c denote statistical significance at the $1 \%, 5 \%$, and $10 \%$ levels, respectively. 
Table 9:

Aircraft Age and Aviation Regulation

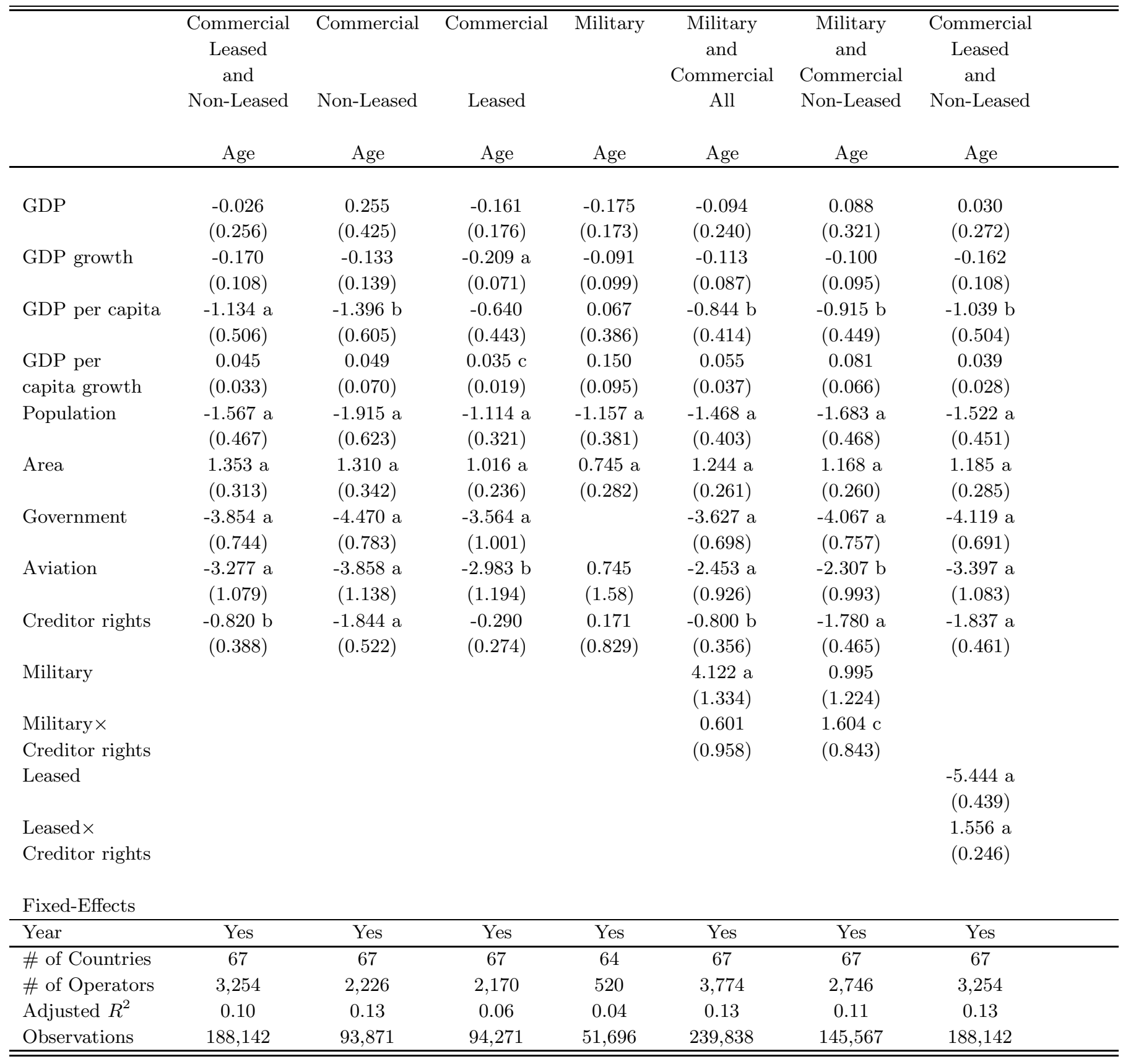

The dependent variable is aircraft age of commerical non-leased aircraft, commercial leased aircraft, or military aircraft. GDP is the natural logarithm of real GDP, GDP growth is the annual growth rate of GDP, GDP per capita is the natural logarithm of real GDP per capita, GDP per capita growth is the annual growth rate of GDP per capita. Population is the natural logarithm of the population. Area is the natural logarithm of the country surface in sq. $\mathrm{km}$. Government is a dummy variable that equals one if the airline operating the aircraft is at least partially owned by the government and equals zero otherwise. Aviation is a dummy variable that equals one for aircraft in countries that comply with ICAO standards and equals zero otherwise. Military is a dummy variable that equals one for military aircraft and zero otherwise. Leased is a dummy variable that equals one for leased aircraft and zero otherwise. Creditor rights is an index aggregating creditor rights, following Djankov et al. (2007). The index ranges from 0 (weak creditor rights) to 4 (strong creditor rights) and is constructed as of January for every year from 1978 to 2003. All regressions include an intercept (not reported), legal origins dummies, and year fixed effects. Standard-errot 8 are clustered by country and reported in parentheses. a, b and c denote statistical significance at the $1 \%, 5 \%$, and $10 \%$ levels, respectively. 
Table 10:

Creditor Rights, Leverage and Aircraft Age: Leased vs. Non-Leased Aircraft

\begin{tabular}{|c|c|c|c|c|c|c|c|c|}
\hline & $\begin{array}{c}\text { Non-Leased } \\
\text { Age }\end{array}$ & $\begin{array}{c}\text { Leased } \\
\text { Age }\end{array}$ & $\begin{array}{c}\text { Non-Leased } \\
\text { Age }\end{array}$ & $\begin{array}{c}\text { Leased } \\
\text { Age }\end{array}$ & $\begin{array}{c}\text { Non-Leased } \\
\text { Age }\end{array}$ & $\begin{array}{c}\text { Leased } \\
\text { Age }\end{array}$ & $\begin{array}{c}\text { Non-Leased } \\
\text { Age }\end{array}$ & $\begin{array}{c}\text { Leased } \\
\text { Age }\end{array}$ \\
\hline GDP & $\begin{array}{c}0.982 \mathrm{~b} \\
(0.437)\end{array}$ & $\begin{array}{c}-0.328 \mathrm{c} \\
(0.179)\end{array}$ & $\begin{array}{l}0.839 \mathrm{c} \\
(0.440)\end{array}$ & $\begin{array}{l}-0.261 \\
(0.213)\end{array}$ & $\begin{array}{l}0.942 \mathrm{a} \\
(0.431)\end{array}$ & $\begin{array}{c}-0.396 \mathrm{~b} \\
(0.184)\end{array}$ & $\begin{array}{l}0.852 \mathrm{c} \\
(0.432)\end{array}$ & $\begin{array}{l}-0.325 \\
(0.220)\end{array}$ \\
\hline GDP growth & $\begin{array}{c}0.102 \\
(0.108)\end{array}$ & $\begin{array}{l}-0.023 \\
(0.036)\end{array}$ & $\begin{array}{c}164 \mathrm{c} \\
(0.084)\end{array}$ & $\begin{array}{l}-0.011 \\
(0.036)\end{array}$ & $\begin{array}{c}0.089 \\
(0.114)\end{array}$ & $\begin{array}{l}-0.025 \\
(0.036)\end{array}$ & $\begin{array}{l}0.171 \mathrm{c} \\
(0.087)\end{array}$ & $\begin{array}{c}0.008 \\
(0.038)\end{array}$ \\
\hline GDP per capita & $\begin{array}{c}0.025 \\
(0.839)\end{array}$ & $\begin{array}{l}0.994 \mathrm{a} \\
(0.285)\end{array}$ & $\begin{array}{c}0.022 \\
(2.366)\end{array}$ & $\begin{array}{l}-1.404 \\
(2.154)\end{array}$ & $\begin{array}{l}-0.016 \\
(0.836)\end{array}$ & $\begin{array}{l}0.944 \mathrm{a} \\
(0.294)\end{array}$ & $\begin{array}{l}-0.269 \\
(2.339)\end{array}$ & $\begin{array}{l}-1.203 \\
(2.255)\end{array}$ \\
\hline $\begin{array}{l}\text { GDP per } \\
\text { capita growth }\end{array}$ & $\begin{array}{l}-0.023 \\
(0.016)\end{array}$ & $\begin{array}{c}0.020 \mathrm{a} \\
(0.005)\end{array}$ & $\begin{array}{l}-0.020 \\
(0.029)\end{array}$ & $\begin{array}{l}0.020 \mathrm{a} \\
(0.003)\end{array}$ & $\begin{array}{l}-0.023 \\
(0.015)\end{array}$ & $\begin{array}{l}0.021 \mathrm{a} \\
(0.006)\end{array}$ & $\begin{array}{l}-0.023 \\
(0.030)\end{array}$ & $\begin{array}{l}0.019 \mathrm{a} \\
(0.003)\end{array}$ \\
\hline Population & $\begin{array}{l}-0.119 \\
(0.332)\end{array}$ & $\begin{array}{l}0.614 \mathrm{~b} \\
(0.264)\end{array}$ & $\begin{array}{l}-14.966 \\
(17.276)\end{array}$ & $\begin{array}{c}9.332 \\
(9.441)\end{array}$ & $\begin{array}{l}-0.085 \\
(0.310)\end{array}$ & $\begin{array}{l}0.654 \mathrm{~b} \\
(0.251)\end{array}$ & $\begin{array}{l}-16.029 \\
(16.878)\end{array}$ & $\begin{array}{c}9.234 \\
(9.266)\end{array}$ \\
\hline Area & $\begin{array}{c}0.399 \\
(0.255)\end{array}$ & $\begin{array}{c}0.023 \\
(0.206)\end{array}$ & $\begin{array}{c}7.281 \\
(63.774)\end{array}$ & $\begin{array}{c}-102.413 \mathrm{a} \\
(5.306)\end{array}$ & $\begin{array}{c}0.404 \\
(0.258)\end{array}$ & $\begin{array}{c}0.046 \\
(0.203)\end{array}$ & $\begin{array}{c}4.121 \\
(62.968)\end{array}$ & $\begin{array}{c}-97.970 \mathrm{a} \\
(5.591)\end{array}$ \\
\hline Government & $\begin{array}{l}-1.507 \\
(1.378)\end{array}$ & $\begin{array}{c}0.123 \\
(0.556)\end{array}$ & $\begin{array}{c}1.537 \\
(1.042)\end{array}$ & $\begin{array}{c}1.421 \\
(1.232)\end{array}$ & $\begin{array}{l}-1.564 \\
(1.444)\end{array}$ & $\begin{array}{l}-0.020 \\
(0.571)\end{array}$ & $\begin{array}{c}1.594 \\
(1.068)\end{array}$ & $\begin{array}{c}1.420 \\
(1.258)\end{array}$ \\
\hline Aviation & $\begin{array}{l}-8.643 \\
(3.240)\end{array}$ & $\begin{array}{c}-6.415 \mathrm{a} \\
(1.548)\end{array}$ & $\begin{array}{l}4.474 \mathrm{a} \\
(1.399)\end{array}$ & $\begin{array}{l}1.614 \mathrm{a} \\
(0.419)\end{array}$ & $\begin{array}{c}-8.969 \mathrm{~b} \\
(3.303)\end{array}$ & $\begin{array}{c}-6.880 \mathrm{a} \\
(1.569)\end{array}$ & $\begin{array}{l}4.606 \mathrm{a} \\
(1.467)\end{array}$ & $\begin{array}{l}1.630 \mathrm{a} \\
(0.428)\end{array}$ \\
\hline Creditor rights & $\begin{array}{c}0.426 \\
(0.686)\end{array}$ & $\begin{array}{l}-0.029 \\
(0.572)\end{array}$ & $\begin{array}{c}1.342 \\
(0.793)\end{array}$ & $\begin{array}{c}0.275 \\
(0.854)\end{array}$ & $\begin{array}{c}0.315 \\
(0.783)\end{array}$ & $\begin{array}{l}-0.115 \\
(0.511)\end{array}$ & $\begin{array}{c}0.910 \\
(0.805)\end{array}$ & $\begin{array}{c}0.104 \\
(0.789)\end{array}$ \\
\hline Leverage & $\begin{array}{l}6.581 \mathrm{~b} \\
(3.224)\end{array}$ & $\begin{array}{l}4.330 \mathrm{a} \\
(1.546)\end{array}$ & $\begin{array}{l}9.038 \mathrm{a} \\
(2.923)\end{array}$ & $\begin{array}{l}3.947 \mathrm{~b} \\
(1.538)\end{array}$ & & & & \\
\hline $\begin{array}{l}\text { Creditor rights } \\
\times \text { Leverage }\end{array}$ & $\begin{array}{c}-3.158 \mathrm{~b} \\
(1.378)\end{array}$ & $\begin{array}{l}-0.279 \\
(0.946)\end{array}$ & $\begin{array}{c}-5.067 \mathrm{a} \\
(1.626)\end{array}$ & $\begin{array}{c}0.204 \\
(1.020)\end{array}$ & & & & \\
\hline LT Debt & & & & & $\begin{array}{c}5.719 \\
(4.381)\end{array}$ & $\begin{array}{l}3.786 \mathrm{a} \\
(1.350)\end{array}$ & $\begin{array}{l}9.412 \mathrm{~b} \\
(3.648)\end{array}$ & $\begin{array}{c}3.140 \mathrm{~b} \\
(1.399)\end{array}$ \\
\hline $\begin{array}{l}\text { Creditor rights } \\
\times \mathrm{LT} \text { Debt }\end{array}$ & & & & & $\begin{array}{c}-3.212 \mathrm{c} \\
(1.782)\end{array}$ & $\begin{array}{l}-0.116 \\
(0.899)\end{array}$ & $\begin{array}{c}-5.737 \mathrm{~b} \\
(2.178)\end{array}$ & $\begin{array}{c}0.510 \\
(1.007)\end{array}$ \\
\hline \multicolumn{9}{|l|}{ Fixed-Effects } \\
\hline Year & Yes & Yes & Yes & Yes & Yes & Yes & Yes & Yes \\
\hline Country & No & No & Yes & Yes & No & No & Yes & Yes \\
\hline \# of Countries & 28 & 28 & 28 & 28 & 28 & 28 & 28 & 28 \\
\hline Adjusted $R^{2}$ & 0.11 & 0.05 & 0.13 & 0.06 & 0.11 & 0.04 & 0.13 & 0.06 \\
\hline Observations & 33,652 & 29,384 & 33,652 & 29,384 & 33,652 & 29,384 & 33,652 & 29,384 \\
\hline
\end{tabular}

The dependent variable is aircraft age of either leased or non-leased aircraft. GDP is the natural logarithm of real GDP, GDP growth is the annual growth rate of GDP, GDP per capita is the natural logarithm of real GDP per capita, GDP per capita growth is the annual growth rate of GDP per capita. Population is the natural logarithm of the population. Area is the natural logarithm of the country surface in sq. $\mathrm{km}$. Government is a dummy variable that equals one if the airline operating the aircraft is at least partially owned by the government and equals zero otherwise. Aviation is a dummy variable that equals one for aircraft in countries that comply with ICAO standards and equals zero otherwise. Creditor rights is an index aggregating creditor rights, following Djankov et al. (2007). The index ranges from 0 (weak creditor rights) to 4 (strong creditor rights) and is constructed as of January for every year from 1978 to 2003. Leverage is total debt divided by total assets. LT Debt is long-term debt divided by total assets. Columns 1,2,5 and 6 also include dummies for French legal origin, German legal origin, Nordic legal origin, and Socialist legal origin (not reported for brevity). All regressions include an intercept (not reported) and year fixed effects. Standard-errors are clustered by country and reported in parentheses. a, b and c denote statistical significance at the $1 \%, 5 \%$, and $10 \%$ levels, respectively. 
Table 11:

Creditor Rights and Fleet Size: Commercial Vs. Military Aircraft

\begin{tabular}{|c|c|c|c|c|c|c|c|c|}
\hline Size $=$ & $\begin{array}{c}\text { Commercial } \\
\text { Number }\end{array}$ & $\begin{array}{l}\text { Military } \\
\text { Number }\end{array}$ & $\begin{array}{c}\text { Commercial } \\
\text { Seats }\end{array}$ & $\begin{array}{c}\text { Military } \\
\text { Seats } \\
\end{array}$ & $\begin{array}{c}\text { Commercial } \\
\text { Weight }\end{array}$ & $\begin{array}{c}\text { Military } \\
\text { Weight }\end{array}$ & $\begin{array}{c}\text { Commercial } \\
\text { Wings }\end{array}$ & $\begin{array}{c}\text { Military } \\
\text { Wings }\end{array}$ \\
\hline GDP & $\begin{array}{c}0.024 \mathrm{~b} \\
(0.011)\end{array}$ & $\begin{array}{c}0.022 \\
(0.097)\end{array}$ & $\begin{array}{c}0.060 \mathrm{~b} \\
(0.026)\end{array}$ & $\begin{array}{l}0.116 \mathrm{~b} \\
(0.052)\end{array}$ & $\begin{array}{c}0.088 \mathrm{~b} \\
(0.038)\end{array}$ & $\begin{array}{c}0.070 \\
(0.055)\end{array}$ & $\begin{array}{c}0.061 \mathrm{~b} \\
(0.025)\end{array}$ & $\begin{array}{c}0.073 \\
(0.044)\end{array}$ \\
\hline GDP growth & $\begin{array}{l}-0.006 \\
(0.004)\end{array}$ & $\begin{array}{c}-0.006 \mathrm{a} \\
(0.036)\end{array}$ & $\begin{array}{l}-0.011 \\
(0.020)\end{array}$ & $\begin{array}{c}0.001 \\
(0.005)\end{array}$ & $\begin{array}{l}-0.011 \\
(0.010)\end{array}$ & $\begin{array}{c}-0.047 \mathrm{~b} \\
(0.006)\end{array}$ & $\begin{array}{l}-0.012 \\
(0.009)\end{array}$ & $\begin{array}{c}-0.014 \mathrm{a} \\
(0.005)\end{array}$ \\
\hline GDP per capita & $\begin{array}{l}0.227 \mathrm{a} \\
(0.056)\end{array}$ & $\begin{array}{c}0.328 \mathrm{~b} \\
(0.129)\end{array}$ & $\begin{array}{l}0.616 \mathrm{a} \\
(0.154)\end{array}$ & $\begin{array}{c}0.597 \\
(0.477)\end{array}$ & $\begin{array}{l}0.611 \mathrm{a} \\
(0.166)\end{array}$ & $\begin{array}{c}0.921 \mathrm{~b} \\
(0.439)\end{array}$ & $\begin{array}{l}0.508 \mathrm{a} \\
(0.129)\end{array}$ & $\begin{array}{l}0.775 \mathrm{~b} \\
(0.309)\end{array}$ \\
\hline $\begin{array}{l}\text { GDP per } \\
\text { capita growth }\end{array}$ & $\begin{array}{l}-0.001 \\
(0.003)\end{array}$ & $\begin{array}{l}0.002 \mathrm{~b} \\
(0.001)\end{array}$ & $\begin{array}{c}-0.0003 \\
(0.007)\end{array}$ & $\begin{array}{c}-0.007 \mathrm{~b} \\
(0.003)\end{array}$ & $\begin{array}{l}0.007 \mathrm{a} \\
(0.006)\end{array}$ & $\begin{array}{l}0.005 \mathrm{c} \\
(0.003)\end{array}$ & $\begin{array}{l}-0.001 \\
(0.006)\end{array}$ & $\begin{array}{l}0.004 \mathrm{c} \\
(0.002)\end{array}$ \\
\hline Population & $\begin{array}{c}0.047 \\
(0.133)\end{array}$ & $\begin{array}{c}0.047 \\
(0.213)\end{array}$ & $\begin{array}{c}0.217 \\
(0.324)\end{array}$ & $\begin{array}{c}0.113 \\
(0.763)\end{array}$ & $\begin{array}{c}0.244 \\
(0.337)\end{array}$ & $\begin{array}{l}-0.323 \\
(0.921)\end{array}$ & $\begin{array}{c}0.096 \\
(0.298)\end{array}$ & $\begin{array}{c}0.036 \\
(0.574)\end{array}$ \\
\hline Area & $\begin{array}{l}-0.106 \\
(0.105)\end{array}$ & $\begin{array}{c}0.360 \\
(0.286)\end{array}$ & $\begin{array}{l}-0.202 \\
(0.271)\end{array}$ & $\begin{array}{c}0.411 \\
(0.923)\end{array}$ & $\begin{array}{l}-0.104 \\
(0.297)\end{array}$ & $\begin{array}{c}1.354 \\
(1.091)\end{array}$ & $\begin{array}{l}-0.184 \\
(0.251)\end{array}$ & $\begin{array}{c}0.746 \\
(0.726)\end{array}$ \\
\hline Government & $\begin{array}{l}-0.007 \\
(0.027)\end{array}$ & & $\begin{array}{c}0.310 \\
(0.218)\end{array}$ & & $\begin{array}{c}0.118 \\
(0.214)\end{array}$ & & $\begin{array}{c}0.077 \\
(0.234)\end{array}$ & \\
\hline Creditor rights & $\begin{array}{c}0.055 \mathrm{~b} \\
(0.027)\end{array}$ & $\begin{array}{c}-0.061 \\
(0.049)\end{array}$ & $\begin{array}{l}0.182 \mathrm{a} \\
(0.062)\end{array}$ & $\begin{array}{c}0.009 \\
(0.118)\end{array}$ & $\begin{array}{c}0.183 \mathrm{~b} \\
(0.091)\end{array}$ & $\begin{array}{c}-0.029 \\
(0.126)\end{array}$ & $\begin{array}{c}0.138 \mathrm{~b} \\
(0.059)\end{array}$ & $\begin{array}{c}-0.058 \\
(0.101)\end{array}$ \\
\hline \multicolumn{9}{|l|}{ Fixed-Effects } \\
\hline Year & Yes & Yes & Yes & Yes & Yes & Yes & Yes & Yes \\
\hline Operator & Yes & Yes & Yes & Yes & Yes & Yes & Yes & Yes \\
\hline \# of Countries & 129 & 110 & 129 & 110 & 129 & 110 & 129 & 110 \\
\hline \# of Operators & 5,284 & 616 & 5,284 & 616 & 5,284 & 616 & 5,284 & 616 \\
\hline Adjusted $R^{2}$ & 0.85 & 0.93 & 0.87 & 0.91 & 0.83 & 0.92 & 0.86 & 0.94 \\
\hline Observations & 32,913 & 6,164 & 32,913 & 6,164 & 32,913 & 6,164 & 32,913 & 6,164 \\
\hline
\end{tabular}

The dependent variable is fleet size defined as the logarithm of either 1) the sum of all aircraft operated, (2) the sum of the seat capacities of all aircraft in the fleet, (3) the sum of the maximal takeoff weight of all aircraft in the fleet, and (4) the sum of the wingspans of all aircraft in the fleet. GDP is the natural logarithm of real GDP, GDP growth is the annual growth rate of GDP, GDP per capita is the natural logarithm of real GDP per capita, GDP per capita growth is the annual growth rate of GDP per capita. Population is the natural logarithm of the population. Area is the natural logarithm of the country surface in sq. km. Government is a dummy variable that equals one if the airline operating the aircraft is at least partially owned by the government and equals zero otherwise. Creditor rights is an index aggregating creditor rights, following Djankov et al. (2007). The index ranges from 0 (weak creditor rights) to 4 (strong creditor rights) and is constructed as of January for every year from 1978 to 2003 . All regressions include an intercept (not reported), year fixed effects and operator fixed-effects. Standard-errors are clustered by country and reported in parentheses. a, b and c denote statistical significance at the $1 \%, 5 \%$, and $10 \%$ levels, respectively. 
Table 12:

Aircraft Age and Fleet Size

\begin{tabular}{|c|c|c|c|c|c|c|c|c|}
\hline Size $=$ & Number & Number & Seats & Seats & Wings & Wings & Weight & Weight \\
\hline Fleet size & $\begin{array}{c}-1.231 \mathrm{a} \\
(0.148)\end{array}$ & $\begin{array}{c}-1.286 \mathrm{a} \\
(0.139)\end{array}$ & $\begin{array}{c}-0.428 \mathrm{a} \\
(0.041)\end{array}$ & $\begin{array}{c}-0.433 \mathrm{a} \\
(0.038)\end{array}$ & $\begin{array}{c}-0.521 \mathrm{a} \\
(0.058)\end{array}$ & $\begin{array}{l}-0.533 \\
(0.053)\end{array}$ & $\begin{array}{c}-0.311 \mathrm{a} \\
(0.044)\end{array}$ & $\begin{array}{c}-0.311 \mathrm{a} \\
(0.043)\end{array}$ \\
\hline GDP & $\begin{array}{c}0.407 \\
(0.272)\end{array}$ & $\begin{array}{c}0.476 \\
(0.308)\end{array}$ & $\begin{array}{c}0.398 \\
(0.263)\end{array}$ & $\begin{array}{c}0.472 \\
(0.293)\end{array}$ & $\begin{array}{c}0.403 \\
(0.265)\end{array}$ & $\begin{array}{c}0.474 \\
(0.298)\end{array}$ & $\begin{array}{c}0.408 \\
(0.263)\end{array}$ & $\begin{array}{l}0.493 \mathrm{c} \\
(0.289)\end{array}$ \\
\hline GDP growth & $\begin{array}{l}-0.080 \\
(0.092)\end{array}$ & $\begin{array}{l}0.072 \mathrm{~b} \\
(0.031)\end{array}$ & $\begin{array}{l}-0.067 \\
(0.089)\end{array}$ & $\begin{array}{l}0.078 \mathrm{~b} \\
(0.032)\end{array}$ & $\begin{array}{l}-0.071 \\
(0.090)\end{array}$ & $\begin{array}{l}0.077 \mathrm{~b} \\
(0.031)\end{array}$ & $\begin{array}{l}-0.069 \\
(0.091)\end{array}$ & $\begin{array}{c}0.081 \mathrm{~b} \\
(0.033)\end{array}$ \\
\hline GDP per capita & $\begin{array}{c}-0.581 \text { c } \\
(0.348)\end{array}$ & $\begin{array}{c}-3.611 \mathrm{a} \\
(0.835)\end{array}$ & $\begin{array}{c}-0.600 \mathrm{c} \\
(0.356)\end{array}$ & $\begin{array}{c}-3.451 \mathrm{a} \\
(0.765)\end{array}$ & $\begin{array}{c}-0.574 \mathrm{c} \\
(0.344)\end{array}$ & $\begin{array}{c}-3.573 \mathrm{a} \\
(0.818)\end{array}$ & $\begin{array}{c}-0.733 \mathrm{~b} \\
(0.346)\end{array}$ & $\begin{array}{c}-3.439 \mathrm{a} \\
(0.750)\end{array}$ \\
\hline $\begin{array}{l}\text { GDP per } \\
\text { capita growth }\end{array}$ & $\begin{array}{c}0.088 \\
(0.080)\end{array}$ & $\begin{array}{l}0.051 \mathrm{~b} \\
(0.019)\end{array}$ & $\begin{array}{c}0.081 \\
(0.077)\end{array}$ & $\begin{array}{l}0.054 \mathrm{a} \\
(0.020)\end{array}$ & $\begin{array}{c}0.083 \\
(0.078)\end{array}$ & $\begin{array}{l}0.052 \mathrm{a} \\
(0.019)\end{array}$ & $\begin{array}{c}0.085 \\
(0.078)\end{array}$ & $\begin{array}{c}0.057 \mathrm{a} \\
(0.021)\end{array}$ \\
\hline Population & $\begin{array}{l}-0.221 \\
(0.354)\end{array}$ & $\begin{array}{l}8.592 \mathrm{a} \\
(2.550)\end{array}$ & $\begin{array}{l}-0.276 \\
(0.355)\end{array}$ & $\begin{array}{l}8.688 \mathrm{a} \\
(2.487)\end{array}$ & $\begin{array}{l}-0.233 \\
(0.349)\end{array}$ & $\begin{array}{l}8.557 \mathrm{a} \\
(2.505)\end{array}$ & $\begin{array}{l}-0.417 \\
(0.347)\end{array}$ & $\begin{array}{l}8.916 \mathrm{a} \\
(2.565)\end{array}$ \\
\hline Area & $\begin{array}{c}0.051 \\
(0.311)\end{array}$ & $\begin{array}{c}39.458 \mathrm{~b} \\
(19.130)\end{array}$ & $\begin{array}{c}0.027 \\
(0.305)\end{array}$ & $\begin{array}{l}40.613 \mathrm{~b} \\
(18.938)\end{array}$ & $\begin{array}{c}0.026 \\
(0.305)\end{array}$ & $\begin{array}{c}38.865 \mathrm{~b} \\
(18.697)\end{array}$ & $\begin{array}{c}0.064 \\
(0.309)\end{array}$ & $\begin{array}{l}36.789 \mathrm{c} \\
(19.389)\end{array}$ \\
\hline Government & $\begin{array}{c}-1.665 \mathrm{a} \\
(0.505)\end{array}$ & $\begin{array}{c}-1.018 \mathrm{~b} \\
(0.459)\end{array}$ & $\begin{array}{c}-1.551 \mathrm{a} \\
(0.500)\end{array}$ & $\begin{array}{c}-0.958 \mathrm{~b} \\
(0.434)\end{array}$ & $\begin{array}{c}-1.588 \mathrm{a} \\
(0.505)\end{array}$ & $\begin{array}{c}-0.979 \mathrm{~b} \\
(0.455)\end{array}$ & $\begin{array}{c}-1.911 \mathrm{a} \\
(0.506)\end{array}$ & $\begin{array}{c}-1.442 \mathrm{a} \\
(0.467)\end{array}$ \\
\hline Creditor rights & $\begin{array}{c}-0.980 \mathrm{a} \\
(0.281)\end{array}$ & $\begin{array}{c}-0.653 \mathrm{c} \\
(0.359)\end{array}$ & $\begin{array}{c}-0.951 \mathrm{a} \\
(0.279)\end{array}$ & $\begin{array}{c}-0.669 \mathrm{c} \\
(0.374)\end{array}$ & $\begin{array}{c}-0.956 \mathrm{a} \\
(0.279)\end{array}$ & $\begin{array}{c}-0.655 \mathrm{c} \\
(0.362)\end{array}$ & $\begin{array}{c}-0.930 \mathrm{a} \\
(0.280)\end{array}$ & $\begin{array}{c}-0.676 \mathrm{c} \\
(0.388)\end{array}$ \\
\hline \multicolumn{9}{|l|}{ Fixed-Effects } \\
\hline Year & Yes & Yes & Yes & Yes & Yes & Yes & Yes & Yes \\
\hline Country & No & Yes & No & Yes & No & Yes & No & Yes \\
\hline \# of Countries & 129 & 129 & 129 & 129 & 129 & 129 & 129 & 129 \\
\hline Adjusted $R^{2}$ & 0.18 & 0.23 & 0.18 & 0.23 & 0.17 & 0.23 & 0.17 & 0.22 \\
\hline Observations & 213,250 & 213,250 & 213,250 & 213,250 & 213,250 & 213,250 & 213,250 & 213,250 \\
\hline
\end{tabular}

The dependent variable is is aircraft age of non-leased aircraft. Fleet size defined as the logarithm of either 1) the sum of all aircraft operated, (2) the sum of the seat capacities of all aircraft in the fleet, (3) the sum of the maximal takeoff weight of all aircraft in the fleet, and (4) the sum of the wingspans of all aircraft in the fleet. GDP is the natural logarithm of real GDP, GDP growth is the annual growth rate of GDP, GDP per capita is the natural logarithm of real GDP per capita, GDP per capita growth is the annual growth rate of GDP per capita. Population is the natural logarithm of the population. Area is the natural logarithm of the country surface in sq. $\mathrm{km}$. Government is a dummy variable that equals one if the airline operating the aircraft is at least partially owned by the government and equals zero otherwise. Creditor rights is an index aggregating creditor rights, following Djankov et al. (2007). The index ranges from 0 (weak creditor rights) to 4 (strong creditor rights) and is constructed as of January for every year from 1978 to 2003. All regressions include an intercept (not reported), year fixed effects and operator fixed-effects. Standard-errors are clustered by country and reported in parentheses. a, b and c denote statistical significance at the $1 \%, 5 \%$, and $10 \%$ levels, respectively. 